\title{
Power and Premises: The Contested Meanings of the Abrams Dissent
}

\author{
Laura Weinrib* \\ I. THE ABRAMS TRIAL AND THE AMBIT OF WARTIME SUPPRESSION .....................64 \\ II. THE RED SCARE REINVENTION OF RIGHTS ........................................................75

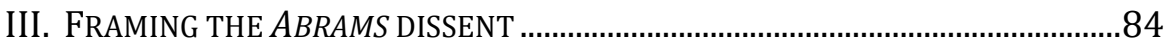 \\ IV. ABRAMS, AMNESTY, AND LEGAL LEGITIMACY …………..............................92

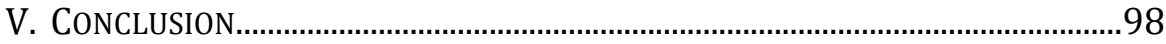

On October 10,1918, four days before United States v. Jacob Abrams went to trial, the government petitioned to sever the case against Jacob Schwartz and proceed against the remaining defendants without him. ${ }^{1}$ Schwartz lay feverish in jail, a casualty of the influenza pandemic that had swept through the overcrowded and windowless cells of the Manhattan prison known as the Tombs. ${ }^{2}$ Fellow radicals attributed his susceptibility to the disease to a severe beating that he allegedly suffered under interrogation for his role in protesting the deployment of American troops to the Soviet Union. ${ }^{3}$ Soon after Judge Henry D. Clayton Jr. granted the government's motion, Schwartz was transferred to the prison ward at Bellevue, though the hospital was already at double its capacity and the morgue had run out of room. ${ }^{4}$ Three days later, Schwartz succumbed to pneumonia. "The hospital records state that he died of Spanish influenza," a pamphlet urging a general amnesty for wartime "political prisoners" relayed, "but his comrades insist that

\footnotetext{
*Professor of Law, Harvard Law School; Suzanne Young Murray Professor, Radcliffe Institute for Advanced Study. I am grateful to participants at "Abrams at 100: A Reassessment of Holmes's 'Great Dissent,"' for helpful comments, and to Columbia Law School, the Knight First Amendment Institute at Columbia University, the First Amendment Clinic at ASU Law, and the Seton Hall Law Review for their generous support of the symposium.

1 Transcript of Record at 20-21, Abrams v. United States, 250 U.S. 616 (1919) (No. 316) [hereinafter Transcript of Record].

2 Richard Polenberg, Fighting Faiths: The Abrams Case, the Supreme Court, and Free SPEECH 91 (1987).

3 Id. at 88-95.

4 Id. at 91.
} 
he was killed by police brutality." 5 His death spared him the twentyyear prison terms that were meted out to most of his alleged coconspirators. At sentencing, defendant Samuel Lipman reflected that he paid dearly for his commitment to the truth, though not as dearly as Schwartz, who had paid with his life. ${ }^{6}$

The centennial of the Supreme Court's decision in Abrams v. United States has occasioned myriad tributes to the birth of the modern First Amendment. Justice Oliver Wendell Holmes Jr.'s testament to the "free trade in ideas" has been exalted for its soaring rhetoric as well as its penetrating distillation of the value of open debate. ${ }^{7}$ In the conventional account, Abrams marked a fateful and fundamental turning point. Before it, judges and juries capitulated to patriotic pressures and accepted the suppression of disfavored ideas as a cost of public safety or of majoritarian democracy. After it, pioneering jurists came to recognize that "time has upset many fighting faiths," and they joined a handful of progressive scholars in erecting judicial enforcement of the First Amendment as a barrier against government overreach. ${ }^{8}$ The Abrams dissent, in short, is a cornerstone of the American free speech tradition.

The thrust of this essay is to suggest that the Abrams dissent was somewhat less momentous than it has been made out to be-or at least, that the case for its greatness is more attenuated than has traditionally been understood. The essay begins with a brief description of the social and political climate that shaped the prosecution and that eventually informed the justices' resolution of the case. It then turns to the early

5 Political Prisoners Def. \& Relief Comm., Sentenced to Twenty Years Prison 14 (1919). Even sympathetic contemporaries were divided over whether the injuries Schwartz sustained during the interrogation were causally linked to his death, given that Schwartz also had an underlying heart condition. Id. at 10; see also Zechariah Chafee Jr., A Contemporary State Trial-The United States Versus Jacob Abrams et al, 33 HARV. L. REv. 747, 762 (1920).

6 Political Prisoners Def. \& Relief Comm., supra note 5, at 30.

7 Abrams v. United States, 250 U.S. 616, 630 (1919) (Holmes, J., dissenting). The dissent has been described as "glorious." See, for example, 1 OLIVER Wendell Holmes \& Harold J. Laski, Holmes-Laski Letters, The Correspondence of Mr. Justice Holmes and HAROLD J. LASKi 222 (1928); Floyd ABRAMs, Friend of THE Court: ON the Front LinES With THE FIRST AMENDMENT 412 (2013). On Holmes's use of the market metaphor, see Vincent Blasi, Holmes and the Marketplace of Ideas, 2004 Sup. CT. REv. 1, 6-13; C. Edwin Baker, Scope of the First Amendment Freedom of Speech, 25 UCLA L. REv. 964, 974-78 (1978).

8 Id. For accounts tracing the modern First Amendment to the Espionage Act prosecutions and the Holmes and Brandeis dissents, see, for example, LEE C. BollingER \& Geoffrey R. Stone, The Free Speech Century (2019); Mark A. Graber, Transforming Free Speech: The Ambiguous Legacy of Civil Libertarianism 2 (1991); Paul L. Murphy, The MEANing of Freedom of Speech: First Amendment Freedoms From Wilson to FDR 8-9 (1972); David M. Rabban, Free Speech in Its Forgotten Years 1 (1997); Geoffrey R. Stone, Perilous Times: Free Speech in Wartime from the Sedition Act of 1798 to the War on TERRorism 230 (2004). 
reception of the Supreme Court's decision and Justice Holmes's fabled dissent among legal scholars and advocates. In so doing, it offers a fuller picture of the perceived significance of the case when it was decided and of the unfamiliar and often counterintuitive uses to which the majority and dissenting opinions were put.

Abrams indeed coincided with a wave of critical commentary among liberals who had previously accepted the suppression of antiwar expression. It is also true that Justice Holmes's dissent was widely disseminated in radical newspapers and the mainstream press. Yet the import of the decision was not its interpretation of the First Amendment, much less a wholesale reimagining of the judicial role. In the immediate aftermath of the decision, legal scholars found Holmes's doctrinal analysis in dissent to be bemusing and inconsistent. Some thought his departure from the majority opinion was narrowly confined, a disagreement about fact more than law or statutory more than constitutional interpretation; others treated his apparent about-face as an artifact of its timing, removed as it was from the exigencies of war, and thus a misapplication of his emerging "clear and present danger" test. ${ }^{9}$ Justice John Hessin Clarke, who wrote the majority opinion, was no paragon of judicial conservatism. As Herbert Goodrich observed in the Michigan Law Review in 1921, "[d] espite the fact that the judges disagreed, it is difficult to put a finger on the exact difference between majority and minority as to the law." 10

In short, in the months after Abrams was decided, hardly anyone imagined the dissent as a harbinger of aggressive First Amendment review of convictions for seditious activity, let alone judicial invalidation of democratically enacted laws. As I have argued elsewhere, it would take at least another decade for that decidedly modern understanding of the First Amendment to take root. ${ }^{11}$ Still, there is no doubt that the Abrams dissent was an important and enduring one. The themes that Abrams pushed into the public spotlight are every bit as relevant as the ones that have been thrust on the decision retroactively.

In the wake of the Abrams case, liberals and radicals deployed Justice Holmes's dissent to generate publicity for a national amnesty of all prisoners who had been prosecuted during the war for their

9 Schenck v. United States, 249 U.S. 47, 52 (1919) ("The question in every case is whether the words used are used in such circumstances and are of such a nature as to create a clear and present danger that they will bring about the substantive evils that Congress has a right to prevent.").

10 Herbert F. Goodrich, Does the Constitution Protect Free Speech, 19 MicH. L. REV. 487, 493 (1921).

11 See generally Laura Weinrib, The Taming of Free Speech: America's Civil Liberties Cомpromise (2016). 
unorthodox beliefs. ${ }^{12}$ They invoked Abrams as a cautionary tale about the susceptibility of illiberal laws to misapplication and abuse, and they urged legislators and public officials to exercise restraint and to model broad-mindedness and tolerance. They held out treatment of the defendants as evidence of longstanding complaints about police brutality and inhumane prison conditions in a period of profound economic inequality, labor unrest, hostility to immigration, and the uncertainty of a global pandemic.

What the Abrams dissent did not do, however, was provoke an immediate reevaluation among progressives of the judicial enforcement of "constitutional limitations," even in the domain of personal rights. ${ }^{13}$ On the contrary, it exacerbated progressive concerns about juror bias, disproportionate sentencing, and weak or vindictive judges. Indeed, it buttressed the belief among many of Justice Holmes's most stalwart supporters that something must be done to cabin the power of the courts.

\section{THE ABRAMS TRIAL AND THE AMBIT OF WARTIME SUPPRESSION}

In the summer of 1918, Jacob Abrams, Hyman Lachowsky, Samuel Lipman, Jacob Schwartz, and Mollie Steimer gathered in Harlem to commiserate over American military interference in Soviet Russia and to devise an appropriate response. ${ }^{14}$ Abrams, Lachowsky, and Schwartz worked as bookbinders. Lipman was a furrier, and Steimer worked in a shirtwaist factory. All five-four of whom were professed anarchists, and the fifth, Lipman, a socialist-were among the nearly half-million Russian Jews who arrived in the United States in the five years before Europe was plunged into war. ${ }^{15}$ None had applied for naturalization. For the time being, all welcomed the Bolshevik Revolution as the realization of their idealistic ambitions for radical political and economic change. ${ }^{16}$

12 See generally Political Prisoners Def. \& Relief Comm., supra note 5.

13 The then-prevailing term for judicial review was most closely associated with Thomas M. Cooley, A Treatise on the Constitutional Limitations Which Rest upon the Legislative PoWer of the States of the AMERiCAN Union (1st ed. 1868).

14 PolenberG, supra note 2, at 41-42.

15 Id. at 4-11 (providing a detailed account of the defendants and of the events leading up to the arrests).

16 By the time the defendants were deported to the Soviet Union in November 1921, Steimer (and many other anarchists) had soured on the Revolution. See, e.g., Girl Won't Accept Deportation Offer, N.Y. Times, July 15, 1921 ("Steimer, who thinks the experiences of Emma Goldman and Alexander Berkman is evidence that anarchists have a hard time in Russia, refuses to consent [to deportation]."). 
The group resolved to purchase a printing press and distribute pamphlets urging American workers to support the revolution. The resulting leaflets decried President Woodrow Wilson's decision to dispatch American troops to Vladivostok, Russia. Although Wilson had issued a statement disclaiming intervention in Russia's "internal affairs," the troops were deployed alongside the Allied expeditions that were assisting the anti-Communist White Russians in their struggle against the Bolsheviks. ${ }^{17}$ That decision was premised on alleged Soviet support for Germany, a justification that American radicals (and most subsequent historians) dismissed as a pretext.18 Incensed by the perceived betrayal, Lipman prepared an English circular that condemned Wilson as a "coward" who was unwilling to admit openly that "capitalistic nations cannot afford to have a proletarian republic in Russia."19 He denounced capitalism as the "enemy of the workers of the world" and called upon Russian emigrants to "Rise!" and to "Put down your enemy and mine!" 20 A separate Yiddish pamphlet written by Schwartz went further. It urged the workers to "spit in the face [of] the false, hypocritic, military propaganda," warning that liberty loans were funding the production of bullets that were used against Soviet workers, and that "[w]orkers in the ammunition factories" were churning out weapons to "murder ... your dearest, best, who are in Russia and are fighting for freedom." 21 In an unguarded call to action, the pamphlet boldly declared that "our reply to the barbaric intervention has to be a general strike!"22 It enjoined "all rulers" to remember "that the hand of the revolution will not shiver in a fight." 23

In August, with the assistance of a sympathetic acquaintance, Hyman Rosansky, who later disclosed their identities to the authorities, Lachowsky and Steimer distributed thousands of copies of the leaflets in the streets of New York. ${ }^{24}$ Along with Abrams, Lipman, and Schwartz, they were arrested and charged with violation of the 1917 Espionage Act and its 1918 (Sedition Act) amendments. Attorney Harry

17 See George F. Kennan, The Decision to Intervene, in Soviet-American Relations, 1917-1920, 482-85 (Princeton Univ. Press 1989) (1958).

18 See PolenBerg, supra note 2 , at 117.

19 Transcript of Record, supra note 1, at 16.

20 Id. at 17

21 Id. at 18-19.

22 Id. at 19.

23 Id. The English translation of the Yiddish pamphlet quoted here, which was entered into evidence in the trial, contained some errors. See PolEnBERG, supra note 2, at 51-53.

24 Abrams v. United States, 250 U.S. 616, 618 (1919). Rosansky attracted attention by throwing the pamphlets from a high window, which prompted the inquiry and subsequent arrests. See id. 
Weinberger, a seasoned veteran of constitutional contestation over repressive wartime legislation, defended all of them in the Southern District of New York and on appeal to the United States Supreme Court. In October 1918, a jury swiftly and unanimously convicted them. ${ }^{25}$ One year later, a seven-justice majority of the Supreme Court upheld their convictions in Abrams v. United States. ${ }^{26}$

As the Abrams case wound its way through the courts, the United States was on the brink of transition from "war hysteria" to "Red hysteria." 27 The conversion was a matter of degree rather than kind. Since its entry into World War I in the spring of 1917, the country had been swept up in jingoistic repression. Public officials and ordinary Americans had closed ranks to stomp out interference with the nation's war aims and the tools of military mobilization, including industrial production and conscription. ${ }^{28}$ The Committee on Public Information had worked to boost support for the war effort, while Congress dutifully enacted legislation to criminalize opposition. ${ }^{29}$ From the outset, such laws were invoked not only against pro-German propaganda but also against the disaffected radicals who regarded the conflict as a concession to Wall Street profiteers. ${ }^{30}$ Although officials brushed off allegations that they were "us[ing] the war as a means to crush labor," 31 critics were quick to point out how many of the most prominent Espionage Act prosecutions had targeted radical defendants. The

25 For a comprehensive account of the trial, see POLENBERG, supra note 2, at 82-117. A seventh defendant and friend of Abrams's, Gabriel Prober, was not involved in printing or distributing the leaflets and was found not guilty.

26 On the Supreme Court's decision, see generally POLENBERG, supra note 2; THOMAS Healy, The Great Dissent: How Oliver Wendell Holmes Changed His Mind-And Changed THE History OF FreE SPEECH IN AMERICA (2013).

27 See The Red Hysteria, NEw Republic, Jan. 28, 1920, at 249-53. See generally Laura Weinrib, Against Intolerance: The Red Scare Roots of Legal Liberalism, 18 J. GILDED AGE \& Progressive ERA 7 (2019).

28 See Christopher Capozzola, Uncle Sam Wants You: World War I and the MaKing of THE Modern American Citizen 7-11 (2008); David M. Kennedy, Over Here: The First World WAR AND AMERICAN SOCIETY 45-59 (1980).

29 On the Committee on Public Information, see RoberT H. ZiEgER, AMERICA's Great WAR: WORLD WAR I AND THE AMERICAN EXPERIENCE 78-84 (2000); see also STEPHEN VAUGHN, Holding Fast the InNer Lines: Democracy, Nationalism, and the Committee on Public INFORMATION (1980).

30 The targets included socialists and the Industrial Workers of the World ("IWW"). See, for example, Michael Kazin, War Against War: The American Fight for Peace, 1914-1918 (2017); C. Roland Marchand, The American Peace Movement and Social REFoRm, 1889-1918 244-48 (1972); JAMEs Weinstein, The DeCline OF Socialism In AMERICA, 1912-1925 ch. 3 (1967).

31 Resolution, in Am. Civil Liberties Union Records, The Roger Baldwin Years, 1917-1950 vol. 3, 109 [hereinafter ACLU Papers] (on file with Princeton University Seeley G. Mudd Manuscript Library, Public Policy Papers). 
casualties included practically the entire leadership of the Industrial Workers of the World ("IWW"), along with socialists Charles Schenck and Eugene V. Debs. ${ }^{32}$

With few exceptions, convictions under the wartime legislation were practically pro forma. ${ }^{33}$ One of the first important cases raised hopes among radical defendants that judges might exercise moderation. When the Postmaster General attempted to shut down The Masses, a respected socialist magazine, the Civil Liberties Bureau of the American Union Against Militarism (AUAM) organized a defense fund, and lawyer Gilbert Roe represented the publication and its staff. ${ }^{34}$ Antiwar activists and radical dissenters were heartened when Judge Learned Hand decided, as a matter of statutory interpretation, that suppressing The Masses because of its antiwar editorials and political cartoons exceeded the authority conferred on postal officials under the Espionage Act. ${ }^{35}$ Eschewing the oft-invoked "bad tendency" test that held speakers accountable under the wartime legislation for statements likely to lead to prohibited conduct, Judge Hand would have required direct incitement to violation of the law as a condition of conviction under the statute. ${ }^{36}$ Encouraged by his opinion, the Civil Liberties Bureau (which soon reorganized as the National Civil Liberties Bureau (NCLB) and would eventually become the American Civil Liberties Union (ACLU)) launched a national network of lawyers willing to represent defendants in Espionage Act and conscription cases. ${ }^{37}$ In November, however, the

32 See, e.g., Schenck v. United States, 249 U.S. 47 (1919); Debs v. United States, 249 U.S. 211 (1919). On the suppression of the IWW and socialists, see MELVYN DuBOFSKY,WE SHALL BE ALL: A HiSTORY OF THE INDUSTRIAL WORKERS OF THE WORLD 376-97, 438-531 (1969); William Preston JR., Aliens ANd Dissenters: Federal SuPPREssion of RAdicals, 1903-1933 88-117 (1963).

33 The few exceptions include Judges George M. Borquin and Charles Fremont Amidon. There were also some early victories under the Trading with the Enemy Acts as well as local ordinances and state laws. On the whole, however, judges capitulated to popular pressures. See Paul L. Murphy, World War I and the Origin of Civil Liberties in THE United STATES 179-247 (1979); Geoffrey R. Stone, The Origins of the "Bad Tendency" Test: Free Speech in Wartime, 2002 SuP. CT. REv. 411, 415-19 (2002).

34 The Masses was edited by Max Eastman, whose sister, Crystal Eastman, had served as executive secretary of the American Union Against Militarism and was a co-founder of the National Civil Liberties Bureau.

35 Masses Publ'g Co. v. Patten, 244 F. 535, 538 (S.D.N.Y. 1917), rev'd, 246 F. 24 (2d Cir. 1917). Judge Hand's opinion in Masses does not contain the terms "First Amendment" or "Constitution."

36 On the Masses case, see Gerald Gunther, Learned Hand: The Man And the Judge (1994); Gerald Gunther, Learned Hand and the Origins of Modern First Amendment Doctrine: Some Fragments of History, 27 STAN. L. REv. 719 (1975).

37 On the NCLB and early ACLU, see generally RoberT C. CotTRELL, Roger NASH BaldWin and the American Civil Liberties Union (2000); Donald Johnson, The Challenge to American Freedoms: World War I ANd the Rise of the American Civil Liberties Union 
Second Circuit reversed Judge Hand's decision, and The Masses, which lost its second-class mailing privileges, had no choice except to shut down. ${ }^{38}$ Other courts proved equally obliging of the administration's speech-suppressive agenda.

Litigation under the Selective Service Act, passed in May 1917 despite significant opposition, fared even worse. ${ }^{39}$ Officials were confident that "every possible legal contingency was cared for" and that a constitutional challenge to conscription was bound to fail.40 When the Supreme Court considered a spate of convictions under the statute in December, the Solicitor General deemed the defendants' claims "frivolous" and thought it practically unnecessary to "appear and refute them." 41 It was Harry Weinberger, future lawyer for the Abrams defendants, who represented famed anarchists Alexander Berkman and Emma Goldman in the conscription case. ${ }^{42}$ Weinberger was a pacifist and radical individualist who had worked closely with the prewar Free Speech League and categorically opposed state interference with personal liberties, from compulsory vaccination to birth control regulation. ${ }^{43}$ He was also an enthusiastic member of Goldman and Berkman's No-Conscription League, which was organized in opposition to conscription on grounds of internationalism, anti-militarism, and anti-capitalism. ${ }^{44}$

In the spring, Weinberger had approached future NCLB (and ACLU) co-founder Roger Baldwin to propose the creation of an American Legal Defense League to "fight all cases in the United States where free speech, free press or the right peaceably to assemble or to petition the

(1963); Samuel Walker, In Defense of American Liberties: A History of the ACLU (1990); Weinrib, supra note 11; John Fabian WitT, PATRIots AND Cosmopolitans: Hidden Histories OF AMERICAN LAW ch. 3 (2007).

38 Masses Publ'g Co. v. Patten, 246 F. 24, 39 (2d Cir. 1917).

39 Selective Service Act, ch. 15, 40 Stat. 76 (1917); Espionage Act, ch. 30, 40 Stat. 217 (1917). See, e.g., Anti-Registration Pleas Are Ruled Out by Tuttle, July 11, 1917 (newspaper clipping), in ACLU Papers, supra note 31, vol. 46; Broke Draft Law, Get Long Terms, N.Y. WoRLD, Dec. 18, 1917, in ACLU Papers, supra note 31, at vol. 46; Detroit Socialist Given Year in Jail for Not Registering, N.Y. CALL, Nov. 25, 1917, in ACLU Papers, supra note 31, at vol. 46.

40 Doubts Court Test of the Draft Law, July 22, 1917 (newspaper clipping), in ACLU Papers, supra note 31, at vol. 43.

41 Argument Ended in Draft Appeals, N.Y. TRIB., Dec. 14, 1917.

42 Brief on Behalf of the Plaintiffs-in-Error at 25-78, Goldman and Berkman v. United States, 245 U.S. 366 (1918) (No. 702) (arguing that the "Draft Act is unconstitutional").

43 See PolenBerg, supra note 2, at 75-78; WALKER, supra note 37, at 22. On the Free Speech League, see generally RABBAN, supra note 8.

44 Transcript of Record at 114, Ruthenberg v. United States, 245 U.S. 480 (1918) (No. 656) (quoting Manifesto of the No-Conscription League (May 25, 1917)). 
government is invaded." 45 Although Baldwin instead opted to build a new organization for the defense of personal rights within the AUAM,46 Weinberger's advice helped to shape the agenda of the NCLB and constitutional litigation under the wartime legislation more broadly. Weinberger believed that the publication of pamphlets critical of the government and military practices was protected by the First Amendment,47 and he was determined to "re-educate the people, that they have the right to discuss and the right to oppose conscription and ask for its repeal." 48 The short-lived American Legal Defense League initially attracted support from notable progressives, along with the New Republic. ${ }^{49}$ Even the Secretary of War signaled acceptance, if not encouragement, of its program..$^{50}$

In practice, however, Weinberger's legal arguments quickly alienated mainstream sympathizers. Challenging the constitutionality of the Selective Service Act, he argued that the statute's narrowly defined exemptions for particular religious sects violated the Establishment Clause and infringed on religious liberty by inhibiting individual religious choice. ${ }^{51} \mathrm{He}$ went so far as to defend an anarchist's right to refuse to register out of opposition to "uniformed murder" in a war "waged by governments," 52 insisting that "the protection of the Constitution ... is guaranteed to all." 53 Predictably, such claims found little traction in the courts. In the Selective Draft Law Cases, the Supreme Court "pass[ed] without anything but statement the proposition that an establishment of a religion or an interference with the free exercise thereof repugnant to the First Amendment resulted from the exemption clauses of the act," because it considered the "unsoundness" of the

45 Letter from Harry Weinberger to Roger N. Baldwin (Apr. 28, 1917), in ACLU Papers, supra note 31, at vol. 35.

46 Letter from Roger N. Baldwin to Harry Weinberger (June 18, 1917), in ACLU Papers, supra note 31, at vol. 35.

47 Letter from Harry Weinberger to Roger N. Baldwin (Apr. 30, 1917), in ACLU Papers, supra note 31, at vol. 35.

48 Letter from Harry Weinberger to Joy Young (May 2, 1917), in ACLU Papers, supra note 31 , at vol. 35 .

49 See Defense of Free Speech, New Republic, May 12, 1917, at 54; The American Legal Defense League, NaTion, May 31, 1917.

50 Secretary of War Denounces Military Rowdyism-Militarism the Same the World Over, Locomotive Firemen \& Enginemen's MAG., July 15, 1917, at 4 (quoting Letter from Newton Baker to Harry Weinberger).

51 Transcript of Record at 5-6, Kramer v. United States, 245 U.S. 366 (1918) (No. 681). Among other claims, he argued that conscription violated the Thirteenth Amendment.

52 Id. at 23.

53 Id. at 34. 
argument "too apparent to require" further discussion. ${ }^{54}$ In upholding the Selective Service Act, the Court stressed the expansive scope of federal powers when the nation was at war.

Formidable as the existing tools of state-coerced conformity proved to be, authorities clamored for more. In May 1918, Congress debated the infamous Sedition Act amendments to the Espionage Act. The Sedition Act directly prohibited "disloyal, profane, scurrilous, or abusive language about the form of Government of the United States," along with the Constitution, the Armed Forces, and the American flag. ${ }^{5}$ It also criminalized advocacy of "any curtailment of production in this country" of anything "necessary ... to the prosecution of the war ... with intent by such curtailment to cripple or hinder the United States in the prosecution of the war." 56 Violations of these provisions were punishable by twenty years in prison and a $\$ 10,000$ fine. ${ }^{57}$ In contrast to other wartime measures, the bill provoked a spirited debate within and outside Congress. Several legislators stressed the potential for bureaucratic overreach and even partisan abuse, especially in the absence of a statutory safe harbor for truthful criticism. Nonetheless, the bill passed easily, and on May 16, President Wilson happily signed it into law.58 The Abrams defendants were acutely aware of the new "gag act" and the twenty-year prison term that attached to violations, as Mollie Steimer admitted to the officers who arrested her. ${ }^{59}$ In fact Lipman's leaflet expressly "denounc[ed] German militarism" in what was presumably a conscious effort to escape liability under the statute. 60

As events unfolded, Lipman's disclaimer proved woefully insufficient. True, officials within the Department of Justice (belatedly) rejected the theory that criticizing the American intervention in Russia,

54 Selective Draft Law Cases, 245 U.S. 366, 389-90 (1918).

55 Sedition Act of 1918, 40 Stat. 553 (1918).

56 Id.

57 Id.

58 On the terms of the Sedition Act and debate over its passage, see STONE, supra note 8, at 183-91; JoHnSON, supra note 37, at 97-98; MURPHY, supra note 33, at 81, 98-103; and RABBAN, supra note 8, at 250-55.

59 See Transcript of Record, supra note 1, at 83; Two Justices Refuse to Gag Pamphleteers, N.Y. CALL, Nov. 12, 1919 (referring to "gag act"). Steimer was asked whether she knew "at the time [she] distributed these pamphlets that it was a violation of the law." Id. She replied, "Yes, sir... I read in the newspapers that the Espionage Law had passed, and it said that anyone who attacked the United States or who speaks against the uniform of the United States Army or Navy [or] insults the President ... would get twenty years in prison." Id. Abrams, by contrast, testified that he "thought [he] broke no law," because his criticism of the President was protected "under the constitutional right of free speech." Id. at 174.

60 Transcript of Record, supra note 1, at 17. 
without more, was sufficient to constitute an Espionage Act violation. ${ }^{61}$ At the same time, they were persuaded that Schwartz's Yiddish pamphlet crossed the line by calling explicitly for a general strike to hamper military production. ${ }^{62}$ It did not help matters that Abrams presented a forged draft card when he was first apprehended, nor that several of the defendants possessed loaded revolvers. ${ }^{63}$ Among the many Espionage Act convictions eventually affirmed by the Supreme Court, the Abrams case was a poor bet to break the Court's unanimity.

The indictment against the Abrams defendants tracked the language of the Sedition Act. Its first three counts charged the defendants with conspiring, while the United States was at war with Germany, "to unlawfully utter, print, write and publish," first, "disloyal, scurrilous and abusive language about the form of Government of the United States"; second, "language 'intended to bring the form of Government of the United States into contempt, scorn, contumely, and disrepute"'; and third, "language 'intended to incite, provoke and encourage resistance to the United States in said war."'64 The fourth count charged the defendants with conspiring "unlawfully and willfully, by utterance, writing, printing and publication, to urge, incite and advocate curtailment of production of ... ordnance and ammunition" essential to the ongoing war. 65

Given the crowded docket in the Southern District of New York, the case was assigned to a visiting judge from Alabama, Henry DeLamar Clayton, Jr. Although he was best known as sponsor of the Clayton Antitrust Act, with its conspicuous exemption for organized labor, Judge Clayton was an unfortunate selection for the Abrams defendants. An unabashed white supremacist, he despised revolutionaries and German sympathizers in equal measure.66 He was also decidedly unlikely to accept Weinberger's invitation to invalidate the Sedition Act on First Amendment grounds. Judge Clayton believed courts "could not make the law," but rather were "bound by its limitations." 67 At the same time, he was unsympathetic to attacks on judicial review, and he rejected prewar efforts to limit judicial power through the "recall of judges and

61 PolenBerg, supra note 2, at 74.

62 Id.

63 Id. at 48-49.

64 Abrams v. United States, 250 U.S 616, 617 (1919).

65 Id. The complete indictment appears at Transcript of Record, supra note 1, at $2-15$.

66 On Clayton, see Polenberg, supra note 2, at 95-104, and Paul M. Pruitt, Jr., Henry D. Clayton: Plantation Progressive on the Federal Bench, in Paul M. PruitT \& Guy W. HubBS, ED., TAMing AlabAMA: LAWYERS AND REFORMERS, 1804-1929 (2010).

67 Henry D. Clayton, Popularizing Administration of Justice, 8 A.B.A. J. 43, 43 (1922). 
judicial decisions" as misguided-though he thought that modest reform directed toward making the law less technical and more accessible would block the spread, and perhaps even "wholly destroy[]," the twin scourges of Bolshevism and socialism that the war had unleashed on America. ${ }^{68}$ Predictably, Judge Clayton denied Weinberger's motions to dismiss the indictments on the grounds that the Espionage Act was unconstitutionally vague and inconsistent with the First Amendment.69 On October 14, a jury was empaneled, and United States v. Abrams went to trial.

From Harry Weinberger's perspective, the trial offered several important opportunities. As with other wartime cases, Weinberger sought to impugn the constitutionality of the Espionage and Sedition acts and to promote the cause of free speech. He likened the defendants to such martyrs to freedom as Socrates, John Brown, Elijah Lovejoy, and above all to Jesus ${ }^{70}$ - a comparison that Abrams had drawn as well and which bothered Judge Clayton just as much as Abrams's reference to his "forefathers" who had built America on revolution. ${ }^{71}$

Yet to Weinberger, the Abrams trial was about much more than expressive freedom. First and foremost, it was a chance to defend radical advocacy by "putting on the witness-stand men of national reputation" who would discredit American intervention in the Soviet Union. ${ }^{72}$ To that end, Weinberger hoped to elicit testimony from Raymond Robins, a former head of the American Red Cross in Russia, who believed that American intervention in the Soviet Union was premised on misinformation. Weinberger planned to question Robins about the so-called "Sisson documents" purportedly linking Bolshevik Russia to the Kaiser, which Wilson invoked to justify the deployment of American troops (and which were widely disseminated by the Committee on Public Information). Robins had been silenced by government officials; subpoenaed to testify in court, he would have had no choice but to acknowledge publicly his conviction that the documents

68 Id.

69 At trial and in his briefs, Weinberger argued that the Sedition Act was unconstitutional because it was "too uncertain and inexact as to what act or acts are prohibited by it." Transcript of Record, supra note 1, at 260. Vagueness claims had been pursued with some success in other contexts, and Alexander Bickel would later praise vagueness doctrine for its deference to the legislative process. See Alexander M. Bickel, The Supreme Court, 1960 Term-Foreword: The Passive Virtues, 75 HARV. L. REV. 40, 63 (1961). Perhaps, had the Court accepted Weinberger's argument, 1920s progressives might have endorsed it for the same reason, but the Court declined the invitation.

70 Political Prisoners Def. \& Relief Comm., supra note 5, at 21-24.

71 See Transcript of Record, supra note 1, at 194.

72 Political Prisoners Def. \& Relief Comm., supra note 5, at 12. 
were forgeries. ${ }^{73}$ Weinberger hoped the revelation would embarrass the Wilson administration and erode support for America's military presence in Russia, but his aspirations in that regard were thwarted. Judge Clayton cut off all questioning about the legality and wisdom of President Wilson's decision to dispatch troops to Siberia. ${ }^{74}$

For Weinberger, the Abrams trial was also an occasion to build support for a general amnesty of all individuals convicted under the wartime legislation. To that end, he drew attention to officials' aggressive investigative methods. The so-called third degree was a staple of interrogation in early twentieth-century New York, and the defendants had described the use of chilling tactics, "from tearing the hair to pulling the tongue; from black-jacks to the leg of a chair."75 In early September, Schwartz had written in a letter that the arrest "could be compared with the Spanish Inquisition and the blackest pages of man's brutality to man."76 Weinberger sought repeatedly to elicit corroborating testimony from the officers, ${ }^{77}$ but all denied engaging in abuse. ${ }^{78}$

Weinberger also provided the defendants a platform for explaining their actions and aspirations, along with their economic theories. Abrams admitted to being a "revolutionist" and forthrightly declared that he did not "believe in government."79 Mollie Steimer, a "youthful and diminutive radical" who (according to the New York Times) defied "all laws and authorities,"80 testified extensively and unabashedly about the ills of capitalist exploitation. She baldly declared that she did not "believe in such laws" as the Sedition Act and was "trying to defeat" them. ${ }^{81}$ As for the probable effect of a general strike in the munitions factory on the prosecution of the war against Germany, she answered only that she "cared nothing about interfering with the war with Germany, because it does not matter to me." 82

73 See PolenBerg, supra note 2, at 108-16.

74 He allowed Weinberger to read his questions into the record but did not permit the witness to answer them. See Transcript of Record, supra note 1, at 123-33.

75 Political Prisoners Def. \& Relief Comm., supra note 5, at 11 (quoting Letter from Jacob Schwartz to Dear Comrades (Sept. 5, 1918)).

76 Id.

77 Five Bolsheviki Guilty, One Freed of Attacking U.S., N.Y.TRIB., Oct. 24, 1918, at 14.

78 Polenberg concludes that the anarchists' accounts of the abuse, which were reported immediately and were internally consistent, were likely accurate. PolEnBERG, supra note 2, at 67-68.

79 Transcript of Record, supra note 1, at 164.

80 Sentences of Mollie Steimer and Three Co-Plotters Cut to $21 / 2$ Years by President, N.Y. TIMES, Feb. 9, 1921.

81 Transcript of Record, supra note 1, at 219.

82 Id. at 222. 
In short, it was evident from the outset that the "five Bolsheviki," as the New York Tribune called the defendants, had "scant hope of acquittal." 83 That was especially true in light of Judge Clayton's demeanor in conducting the trial, an issue that attracted considerable attention from scholars and advocates in the coming months. Clayton suggested to the jury that the defendants' secrecy betokened illicit intentions, and he intimated that conviction would be appropriate on the basis of their testimony alone. ${ }^{84}$ The New York Tribune reported that Abrams's testimony "so aroused the court that Judge Clayton conducted a cross-examination of his own." 85 He interrupted, spoke over, and ridiculed the witnesses, according to the prosecution-friendly New York Times. ${ }^{86}$

Against this backdrop, the swift convictions of the Abrams defendants were unremarkable. The jury deliberated for a little over an hour before finding Abrams, Steimer, Lachowsky, Lipman, and Rosansky guilty on all four counts. ${ }^{87}$ Given the rate of convictions in Espionage Act cases, neither Weinberger nor the defendants could have considered the verdict surprising; convictions were routinely obtained for much milder remarks under the much narrower provisions of the original Espionage Act.88 More jarring, however, were the unusually long sentences that Clayton meted out. In exchange for cooperating with the government, Rosansky received only three years in prison. The others were sentenced to twenty, except Steimer who, in an apparently paternalistic concession to her gender, received only fifteen. ${ }^{89}$ Like his fellow defendants, Lipman professed to welcome the news. He expressed his hope that the trial would "go on record as a trial not of the United States Government against five individuals, but as a trial of

83 Five Bolsheviki Guilty, One Freed of Attacking U.S., N.Y. TriB., Oct. 24, 1918.

84 See, e.g., Transcript of Record, supra note 1, at 237. ("It is perhaps not amiss for me to say that men who are actuated by pure and lawful motives as a rule act in the open daylight.... So it is proper for you to consider how these leaflets were printed and how they were circulated, as bearing upon the question of the intent that animated these defendants in the circulation of those leaflets.").

85 Thousands of Anarchists Here Still Active, Defendant Asserts, N.Y. TRIB., Oct. 22, 1918. See also Chafee, supra note 5, at 756 ("[I]t is one of the remarkable features of this case that most of the cross-examination of the prisoners was not by the district attorney but by the court....").

86 Bolshevist Witness Curbed by Court, N.Y. Times, Oct. 22, 1918.

87 Five Bolsheviki Guilty, One Freed of Attacking U.S., N.Y.TRIB., Oct. 24, 1918. The jury acquitted Prober, whom the government had failed to link to the distribution of the pamphlets. Id. See generally Transcript of Record, supra note 1, at 240.

88 For representative examples, see STONE, supra note 8, at 171-73.

89 See Mollie Steimer and 3 Youths to Be Released, N.Y. Call, Oct. 16, 1921; see also Prison Terms for the Bolsheviki, N.Y. TRIB., Oct. 26, 1918 ("The sentences are the most severe inflicted in this district since the United States entered the war."). 
Capitalism against Labor." 90 Indeed, he applauded the convictions for revealing the intolerance of American officials and institutions and thereby hastening the revolution. "The more Espionage Acts you pass, the more the lovers of truth you put in prison," he predicted, "the nearer will be the end of poverty, misery, starvation, autocracy, despotism and tyranny." 91

Clayton made clear his view that the defendants "deserve[d]" their harsh sentences. ${ }^{92}$ Still, he thought it possible that if they "behave[d] themselves" there might be "Executive intervention at Washington, and then deportation following Executive intervention."93 In the end, that is precisely what happened, though without the good behavior. Pending appeal, Weinberger raised and posted bail for the defendants (poignantly, he paid in Liberty Bonds). ${ }^{94}$ True to form, the defendants devoted the months before their prison terms commenced to radical agitation. 95

\section{THE RED SCARE REINVENTION OF RIGHTS}

Well before the Abrams case arrived in the Supreme Court, Harry Weinberger was actively framing its narrative. And in the estimation of the Political Prisoners Defense and Relief Committee, he "succeeded in giving their case a national, and even international, significance."96 In part, he sought to deploy the conviction in his longstanding campaign to establish that " $\mathrm{t}]$ he right to speak and the right to publish and distribute pamphlets on the war is an absolute one under the constitution." 97 Legal vindication of that theory, however, was only one component of the struggle. Weinberger had long thought "fine spun legal argument on the Espionage Bill" to be less important than "re-educat[ing] the people."98

90 Political Prisoners Def. \& Relief Comm., supra note 5, at 30.

91 Id.

92 Transcript of Record, supra note 1, at 243.

93 Id. at 244.

94 Doubly Liberty Bonds, N.Y. WorLD, Nov. 16, 1918.

95 See PolEnBerg, supra note 2, at 177-78. The defendants were subject to extensive surveillance while they were out on bail, and Steimer repeatedly clashed with law enforcement. See id. at 177-88. Abrams and Lachowsky attempted to leave the country after the Supreme Court issued its decision but were apprehended in New Orleans aboard a ship bound for Mexico. Id. at 242-46. Steimer, who in any case opposed bail jumping, was in jail at the time for a subsequent offense. Id. at 247.

96 Political Prisoners Def. \& Relief Comm., supra note 5, at 8.

97 Letter from Harry Weinberger to Roger Baldwin (Apr. 28, 1917), in ACLU Papers, supra note 31 , at vol 35.

98 Letter from Harry Weinberger to Joy Young (May 2, 1917), in ACLU Papers, supra note 31 , at vol. 35 . 
In that broader effort, legal defeats were every bit as instructive as legal victories. ${ }^{99}$

Indeed, by the time Judge Clayton dispensed the sentences in United States v. Abrams, prominent legal defeats like the Masses case had begun to chip away at the complacency about wartime repression that had characterized the first year of the war. Early on, most Americans had either actively embraced wartime censorship as a cost of a successful war effort or had accepted it as a concession to majoritarian democracy. Conservatives had always allowed for a great deal of censorship in the service of public safety and morals; liberty of speech, they insisted, did not encompass license. ${ }^{100}$ Progressives, meanwhile, considered open debate to be essential to social and scientific progress, but they counseled deference to democratically enacted laws, and they were willing to suspend the enjoyment of individual rights for the duration of the war. As Karl Llewellyn put the point in reflecting on the Abrams case, "[o]ne is willing to endure silence, as he is to suffer taxes or the reek and mud of the field, that war may pass and victory be gained."101

These positions were closely linked to the respective contingents' attitudes toward the judiciary and judicial review. Conservatives venerated the courts as the "citadel of civil liberty," by which they meant the institution best equipped to insulate the rights of private property against populist redistribution. ${ }^{102}$ At the same time, although they accepted that other individual rights were also essential to the constitutional design, they were concerned with preserving law and order and believed that radical agitation crossed the line.103 For their part, progressives were deeply skeptical of the courts and of the constitutional rights they purported to enforce. After all, the courts had

99 The NLCB had voiced precisely that sentiment in an early pamphlet. National Civil Liberties Bureau, The Need of a National Defense Fund (Nov. 15, 1917), in ACLU Papers, supra note 31, at vol. 25 (noting that judicial defeats could "show up miscarriage of justice" and thereby stimulate change).

100 See, e.g., Editorials: Constitutional Law: Freedom of Speech, 5 VA. L. REG. N.S. 712, 715-16 (1920) ('“Freedom of speech' as contemplated by our Constitution was no more intended to allow 'unlicensed speech' than the clause which permitted every citizen to bear arms was intended to allow the carrying of concealed weapons.").

101 K.N.L., Free Speech in Time of Peace, 29 YALE L.J. 337, 340 (1920).

102 Walter George Smith, Civil Liberty in America, Address by Walter George Smith, 4 A.B.A. J. 551, 562 (1918).

103 On the conservative civil liberties movement during the 1910s and 1920s, see Graber, supra note 8, at 19-46. See also DAvid Bernstein, ReHABILITATING Lochner: Defending Individual Rights against Progressive Reform 3-7 (2011); Kenneth I. Kersch, Constructing Civil Liberties: Discontinuities in the Development of American Constitutional LaW 1-2, 11-17, 21 (2004). 
invoked the Constitution to invalidate many of progressives' most celebrated legislative accomplishments, from workers' compensation to the minimum wage.104 The same month that Harry Weinberger argued the Selective Draft Law Cases before the Supreme Court, a decision in a high profile labor case prompted the progressive New Republic to reflect that "a majority of the Supreme Court are endeavoring to enforce their own reactionary views of public policy, in direct opposition to the more enlightened views prevailing in legislatures and among the public."105

As a radical individualist who defended anarchists, Weinberger's beliefs aligned almost as awkwardly with progressives' views as they did with conservatives' views. Over the course of the war, however, progressives began to reevaluate their position on free speech and eventually even constitutional rights, if not the judiciary as an institution. The trajectory is neatly captured by the ruminations of the philosopher John Dewey in the New Republic.106 In September 1917, he denied the prospect of widespread suppression and relished the irony of "ultra-socialists rallying to the ... sanctity of individual rights and constitutional guaranties."107 Two months later, as the scope of government repression became increasingly indisputable, Dewey revised his position. He declined to embrace individual autonomy, but he endorsed wartime tolerance by reference to pluralism and the social good. ${ }^{108}$ Zechariah Chafee Jr. would make much the same move in the spring of 1919 in the pages of the Harvard Law Review, in an article that famously influenced Justice Holmes's dissent in Abrams v. United States. 109

104 On progressives' hostility toward the courts and rights-based constitutionalism, see, for example, Eldon J. Eisenach, The Lost Promise of Progressivism 3-5 (1994); William E. Forbath, LaW and the Shaping of the American Labor Movement 2, 8 (1991); Morton J. Horwitz, The Transformation of American LaW, 1870-1960: The Crisis OF Legal Orthodoxy 4-6 (1992); William G. Ross, A Muted Fury: Populists, Progressives, and Labor Unions Confront the CourTs, 1890-1937 1-2, 12-21 (1994); Laura Kalman, In Defense of Progressive Legal Historiography, 36 L. \& Hist. REV. 1021, 1021, 1024, 1032, 1034 (2018); Daniel T. Rodgers, In Search of Progressivism, 10 REvs. AM. HIST. 113, 114, 117, 126 (1982).

105 Breaking the Labor Truce, New RepuBlic, Dec. 22, 1917, at 197 (discussing Hitchman Coal \& Coke Co. v. Mitchell, 245 U.S. 229 (1917)).

106 On Dewey's about-face, see GRABER, supra note 8, at 98; KENNEDY, supra note 28, at 50-53, 90-92; RABBAN, supra note 8, at 243-45; and ROBERT B. WESTBROOK, JOHN DEWEY AND AMERICAN DEMOCRACY 202-12 (1991).

107 John Dewey, Conscription of Thought, New Republic, Sept. 1, 1917, at 128-30.

108 John Dewey, In Explanation of Our Lapse, New Republic, Nov. 3, 1917, at 17-18.

109 See Zechariah Chafee, Freedom of Speech in War Time, 32 HARv. L. REv. 932, 937 (1919). 
Chafee's may have been the most sustained and significant defense of free speech in the months before Abrams was decided, but its sentiment found considerable company among Holmes's admirers and interlocutors. ${ }^{110}$ The impetus for a broad-based reconsideration of progressive attitudes was the persistence of censorship after the war ended. In November 1918, just weeks after the Abrams trial concluded, the armistice halted the fighting in Europe. It did not, however, ease domestic repression. Instead, the coercive apparatus of the state retrained explicitly on the radicals and revolutionaries who had always been its most frequent targets. 111 The reorientation began even before the cessation of hostilities. In October, Congress modified existing immigration laws to authorize the removal of any alien who was discovered to have espoused anarchist views at any time since entering the country. ${ }^{112}$ With the armistice, the Selective Service and Sedition acts elapsed, but a few pending prosecutions under the Espionage Act continued, and efforts to repeal the statute were unsuccessful.113

To win the "war to end all wars," progressives had seen the suspension of free speech as a worthwhile tradeoff. It helped that industry, too, was asked to sacrifice for the nation's cause-that business leaders feebly complained that their own "civil liberty" was under assault.114 With the armistice, that precarious equilibrium was unsettled. Wilson had "unshackled" industry, Gilbert Roe reflected in December, "but the embargo on ideas remain[ed]."115 In short, the wartime exigencies that so impressed Justice Holmes when Schenck $v$. United States was argued in January, and which he would stress in his March 1919 decision, were becoming increasingly remote. ${ }^{116}$

110 For Holmes's conversations and correspondence with Chafee, Learned Hand, Howard Laski, and Felix Frankfurter, among others, see RABBAN, supra note 8,

at 299-353; HeAly, supra note 26; STEPHEN BudiansKy, OLIVER WENDELl HolmES: A LiFE IN WAR, LAW, AND IDEAS 365-95 (2019).

111 See generally ROBERT K. MURRAY, RED SCARE: A STUDY IN NATIONAL HYSTERIA, 1919-1920 (1955).

112 See Immigration Act of 1918, ch. 186, 39 Stat. 889.

113 Gilbert E. Roe, Repeal the Espionage Law: An Address Delivered Before the Civic Club of New York (December 3, 1918), in DiaL, Jan. 11, 1919, at 8, 10 ("Who, when exercising arbitrary power, ever proposes to repeal the law which silences criticism of the manner in which such power is exercised?").

114 See, e.g., Walter George Smith, Civil Liberty in America, 41 A.B.A. AnN. ReP. 209, 218-20 (1918).

115 Roe, supra note 113 , at 8.

116 Schenck, 249 U.S. at 52 ("When a nation is at war, many things that might be said in time of peace are such a hindrance to its effort that their utterance will not be endured so long as men fight, and that no Court could regard them as protected by any constitutional right."). 
To be sure, there were salient differences between the progressive defense of free speech and the alternative preferred by Weinberger and his clients. The latter imagined unfettered speech as a pathway to radical social and economic transformation; the former considered it the best tool for preventing revolution. The Nation was typical in blaming censorship for "turning the thoughtful working people of the country into dangerous radicals and extreme direct actionists." 117 Stressing the editors' rejection of socialism, the journal endorsed an individual's "right to present for public consideration his ideas, no matter how erroneous they may appear."118 By the same token, Karl Llewellyn cautioned that "[r]epression of expression has in the past meant disorder," and that "stern repression, long-continued, has meant revolution."119 Even President Wilson professed always to have "believe[d] that the greatest freedom of speech was the greatest safety." 120 Whatever his own beliefs, Weinberger played to this concern in his brief to the Supreme Court. The suppression of truthful discussion, he warned, would "only drive people to underground propaganda." 121

The notion that free speech might defuse radical pressures became an increasingly common trope as mounting labor unrest coupled with the specter of revolutionary violence abroad raised new concerns about domestic militancy. During the war, the American Federation of Labor (AFL) (in contrast to the more radical contingents of the American labor movement) had experienced a boom in membership and, in light of labor shortages resulting from foreign deployment of American troops, in political and economic power.122 In November 1918, however, Republicans took control of both chambers of Congress, and the Wilson administration shifted its favor from labor to industry. Soldiers returned to work, and the corresponding labor surplus spurred unions to adopt more aggressive tactics. Increased cost of living exacerbated

117 Danger Ahead, NATION, Feb. 8, 1919, at 186.

118 Id. at 186-877.

119 K.N.L., supra note 101, at 343.

120 Woodrow Wilson, America Is Ready, in The Triumph of Ideals: Speeches, Messages and Addresses Made by the President Between February 24, 1919, ANd July 8, 1919 70, 78 (1919).

121 Brief for Plaintiffs-in-Error at 24, Abrams v. United States, 250 U.S. 616 (1919) (No. 316).

122 See Joseph A. McCartin, Labor's Great War: The Struggle for Industrial Democracy ANd the Origins of Modern American Labor Relations, 1912-1921 174 (1997). On the labor-friendly agenda of the National War Labor Board, see MELVyn DubOFSKY, THE STATE \& Labor in Modern America 72 (1994); see also David Montgomery, The Fall of the House of Labor: The WorkPlace, the State, ANd American Labor Activism, 1865-1925 442-46 (1987). 
complaints about economic inequality. Anti-immigrant sentiment escalated, and race riots roiled the nation. ${ }^{123}$

Most pertinent for the Abrams defendants, concerns about anarchist violence-as well as public support for suppression-reached a fever pitch in the spring of 1919 when bombs were mailed to public officials and other prominent figures. ${ }^{124}$ The radical press denied responsibility, but a leaflet found on the scene was signed "The Anarchist Fighters."125 The new General Intelligence Division of the Bureau of Investigation, under the leadership of the young J. Edgar Hoover, undertook aggressive surveillance of suspected subversives. ${ }^{126}$ Attorney General A. Mitchell Palmer, who had been targeted in the second series of bombings, took full advantage of his power under the new immigration laws to deport foreign-born radicals, including Emma Goldman and Alexander Berkman, along with Samuel Lipman's "sweetheart."127

Congress, too, played its part. The Senate's Overman Committee, initially appointed to investigate pro-German activity among beer brewers, quickly shifted its focus to the Bolshevik threat.128 Its June 1919 report unselfconsciously denounced Bolshevism for abrogating freedom of speech and for erecting a "dictatorship of [a] small minority."129 Majoritarian repression, by contrast, posed no apparent threat to democracy. Indeed, New York's Joint Committee to Investigate Seditious Activities, or Lusk Committee, convened in March for the express purpose of "repression carried on by and with the consent of the vast majority."130 Under the guidance of well-known lawyer and Red-hunter Archibald Stevenson, who had also testified before the Overman Committee, the Lusk Committee would soon assemble comprehensive reports on the Abrams defendants. ${ }^{131}$ Notably,

\footnotetext{
123 Montgomery, supra note 122 , at 388-89.

124 See MURRAY, supra note 111, at 78-80.

125 See Paul Avrich, Sacco and Vanzetti: The Anarchist Background 137-38 (1991).

126 See Murray, supra note 111, at 77-80, 193-200; see also StANLEy CoBEn, A. Mitchell PALMER: Politician 215-21 (1963).

1273 Russians on Way to Prison Under Gag Act, N.Y. CALL, Dec. 27, 1919 (referring to Ethel Bernstein).

128 See Murray, supra note 111, at 226-29. On the Overman Committee, see REgin SCHMIDT, RED SCARE: FBI AND THE ORIGINS OF ANTICOMMUNISM IN THE UNITED STATES, 1919-1943 136-46 (2000).

129 Brewing and Liquor Interests And German and Bolshevik Propaganda, S. Doc. No. 6662, at 31, 36 (1919).

130 Polenberg, supra note 2, at 170. On New York's Lusk Committee, see Todd J. Pfannestiel, Rethinking the Red Scare: The lusk Committee and New York's Crusade AGAINST RADICALISM, 1919-1923 (2003).

131 PoLENBERG, supra note 2, at 171-72.
} 
Stevenson believed the greatest danger to American institutions came from "those quasi-political and economic organizations which teach that the workers should organize into revolutionary industrial unions for the purpose of using the coercive power of the general strike as a means to enable an organized minority ... to impose its will upon the American people." 132

Stevenson's preoccupation with the general strike-the same method that the Abrams defendants had pressed in their pamphletswas not entirely outlandish. The Seattle General Strike of February 1919 prompted frenzied denunciations of worker radicalism and its threat to political and economic stability. ${ }^{133}$ It was followed in the summer and the fall by a massive strike wave involving four million American workers, including the Boston police.134 The AFL, which had largely capitulated to wartime censorship of antiwar speech, "insist[ed] that all restrictions of freedom of speech, press, public assembly, association and travel be completely removed." 135 But its decades-old effort to recast picketing and boycotts as constitutionally protected expression continued to ring hollow. ${ }^{136}$ Federal troops helped to suppress the steel strike, and the administration obtained a federal injunction against striking coal miners. ${ }^{137}$ Rather than take seriously their efforts to bargain for better wages, hours, and working conditions, employers and the mainstream newspapers denounced the strikers as a mix of foreign-born Bolsheviks and their unwitting dupes. ${ }^{138}$ The same progressives who had accepted enforced conformity as the price of defeating the Kaiser doubted the veracity of the Bolshevik threat. Strikers' revolutionary ambitions struck them as a pretext as opposed to a legitimate peril. As Swinburne Hale observed for the New Republic, officials who claimed to be policing "force and violence" were in fact arresting prospective strikers because "they advocated the general strike."139

132 Archibald E. Stevenson, The World War and Freedom of Speech, N.Y. TimES, Feb. 13, 1921, at 33 (reviewing Zechariah Chafee JR., Freedom of SpeEch (1920)).

133 Id. On the Seattle general strike see Robert L. FriedHEM, The SEATTLE GENERAL STRIKE (1964).

134 DuBOFSKY, supra note 122, at 76-79.

135 Resolution No. 108 Adopted by the Thirty-Ninth Annual Convention of the American Federation of Labor, Atlantic City, June 1919, in ACLU Papers, supra note 31, at vol. 69. On the AFL, free speech, and anti-Communism during World War I and the Red Scare, see Jennifer LufF, Commonsense Anticommunism: LABor And Civil Liberties BETWEEN THE WORLD WARS 46-80 (2012).

136 See generally Gompers v. Bucks Stove \& Range Co., 221 U.S. 418 (1911).

137 See David Brody, Labor in Crisis: The Steel Strike of 1919 60-77 (1965).

138 MuRRAY, supra note 111, at 135-65.

139 Swinburn Hale, The Force and Violence Joker, New RepuBLIC, Jan. 21, 1920, at 231. 
Such were the conditions when Harry Weinberger appeared in Washington at the end of October for oral argument in Abrams v. United States, and when the Supreme Court issued its decision just three weeks later. Weinberger pressed essentially the same arguments he had introduced at the trial: the evidence of unlawful activity was insufficient, and the relevant provisions of the Espionage Act were, in any case, unconstitutional. His brief conceded that the leaflets were "intemperate" and "inflammatory." 140 Those were incautious adjectives, given Justice Holmes's propensity for fire metaphors in wartime speech cases. But the thrust of the argument was straightforward. The defendants had engaged in a "public discussion of a public policy in reference to a country with which we were not at war."141 Under the circumstances, conviction was unwarranted under the wartime legislation and incompatible with the protections of the First Amendment.

Both the majority opinion and Justice Holmes's storied dissent, joined by Justice Brandeis, are discussed at length elsewhere in this symposium and an impressive body of prior scholarship. A few points nonetheless bear emphasis. First, the majority opinion devoted little attention to the defendants' constitutional claims, which were argued (in the Court's assessment) "somewhat faintly" and which were "definitively negatived" in the Court's recent decisions. ${ }^{142}$ Second, because the sentences might have been lawfully imposed under any count of the indictment, the majority had only to find the evidence sufficient to sustain any one of the four counts. ${ }^{143}$ Accordingly, it did not need to resolve whether a "technical distinction" might be made between disloyal and abusive language directed to the "form of our government" as opposed to government officials. ${ }^{144}$ That the two had been conflated was a central contention at trial and on appeal. As anarchists, Abrams, Steimer, and Lachowsky surely rejected the American form of government, but the printed pamphlets (in contrast to other materials found among the defendants' belongings) did not say so. Lipman testified that as a socialist, he "believe[d] in government,"

140 Brief for Plaintiffs-in-Error, supra note 121, at 19. Holmes's references to fire include Schenck v. United States, 249 U.S. 47, 52 (1919) ("The most stringent protection of free speech would not protect a man in falsely shouting fire in a theater ...."); and Frohwerk v. United States, 249 U.S. 204, 209 (1919) ("[I]t is impossible to say that it might not have been found that the circulation of the paper was in quarters where a little breath would be enough to kindle a flame....").

141 Brief for Plaintiffs-in-Error, supra note 121, at 19.

142 Abrams v. United States, 250 U.S. 616, 618-19 (1919).

143 Id. at 619.

144 Id. at 623-24. 
albeit the "proper," "not capitalistic" kind. ${ }^{145}$ The defendants stressed repeatedly that the pamphlets denounced the president and his policies, not American democracy. Concededly, the pamphlets also criticized American capitalism-but that, as Zechariah Chafee observed, was an economic rather than "political structure." ${ }^{146}$ As Kate Claghorn reflected in the Survey, equating an attack on capitalism with an attack on the American government "might be giving comfort to those who claim that the government and capitalism are one and the same thing."147

Whatever the majority might have made of these arguments, it did not decide whether the first two counts were sufficiently substantiated, nor whether the sections of the Sedition Act on which they relied were constitutional. Instead, it decided only that there was ample evidence under the third and fourth counts. The defendants sought change not "by candid discussion" but by "bringing upon the country the paralysis of a general strike, thereby arresting the production of all munitions and other things essential to the conduct of the war." 148 In the Court's view, the "manifest purpose" of the pamphlets was to "defeat the war plans of the Government of the United States."149

It was with reference to these counts that Justice Holmes articulated in dissent his distinctive view of the intent required by the statute: "[W]hen words are used exactly," as he concluded was true of the Sedition Act, "a deed is not done with intent to produce a consequence unless that consequence is the aim of the deed."150 That is, "the aim to produce it" must be "the proximate motive of the specific act." 151 Holmes did not believe that Lipman's English pamphlet, with its explicit disdain for German militarism, manifested any such purpose. Schwartz's Yiddish leaflet, "if published for the purposes alleged in the fourth count," could conceivably be punishable.152 It was not enough, however, to point to isolated phrases, divorced from their broader context. Taken as a whole, Holmes concluded that "the only object of the

\footnotetext{
145 Transcript of Record, supra note 1, at 201; see also id. ("The entire leaflet speaks about capitalism and not government.").

146 Chafee, supra note 5, at 753. Chafee added that "our political structure ... is compatible with other types of economic organization, such as national ownership of all industries." Id.

147 Kate Holladay Claghorn, Reassurance from the Supreme Court, SuRvEY, Nov. 22, 1919 , at 148.

148 Abrams v. United States, 250 U.S. 616, 622 (1919).

149 Id.

150 Id. at 627 (Holmes, J., dissenting).

151 Id.

152 Id. at 628.
} 
paper [was] to help Russia and stop American intervention there," not to impede the war against Germany. 153

As for the third count, the Sedition Act made it unlawful to "publish any language intended to incite, provoke, or encourage resistance to the United States," and Holmes interpreted the statute to require "some forcible act of opposition to some proceeding of the United States in pursuance of the war."154 Against that standard, he deemed the requisite specific intent to be lacking. Even if he was "technically wrong," he continued, "the most nominal punishment seems to me all that could possibly inflicted." 155 Anything else would amount to punishment for "the creed that they avow[ed]." 156 And that, as Holmes went on to express so eloquently, would be inconsistent with "the theory of our Constitution."157

\section{FRAMING THE ABRAMS DISSENT}

Commentators were quick to label Holmes's dissent a classic. ${ }^{158}$ Its memorable last paragraphs captured as only Holmes could the value of expressive freedom and the corresponding cost of censorship.159 "Persecution for the expression of opinions seems to me perfectly logical," Holmes famously began. "If you have no doubt of your premises or your power, and want a certain result with all your heart, you naturally express your wishes in law, and sweep away all opposition."160 Given the urgency of the war effort, it was no wonder that public officials and popular opinion had formed a phalanx of suppression. But Holmes did not stop there. "[W] hen men have realized that time has upset many fighting faiths," he continued, "they may come to believe even more than they believe the very foundations of their own conduct that the ultimate good desired is better reached by free trade in ideas-that the best test of truth is the power of the thought to get itself accepted in the competition of the market, and that truth is the only ground upon which their wishes safely can be carried out." 161 Even such critics of the

\footnotetext{
153 Id. at 629.

154 Abrams, 205 U.S. at 617, 629.

155 Id. at 629.

156 Id.

157 Id. at 630 .

158 E.g., The Call to Toleration, New Republic, Nov. 26, 1919, at 360. Notably, Holmes's dissent in Lochner had failed to persuade a Supreme Court majority over the ensuing decades. Progressives had reason to believe the Abrams dissent would suffer the same fate, even as it influenced debate among scholars and policymakers.

159 Abrams, 205 U.S. at 630.

160 Id.

161 Id.
} 
opinion as the antitrust attorney Henry Taft (brother of William Howard Taft) disdainfully acknowledged that Holmes's "eloquent and inspiring, if irrelevant, discourse on the Freedom of Speech" had assumed "epochal importance."162

Yet the meaning of the opinion as a matter of constitutional law was undeniably murky. Most legal scholars found both the majority and dissenting opinions to be ambiguous and the relationship between the two downright bewildering. Thomas F. Carroll argued in the Georgetown Law Journal that "the real issue was concerned with the meaning of the word 'intent,"' and "that the opinion of the Court in Espionage Act cases only indirectly involved the constitutionality of the Espionage Act." 163 To the extent the case involved the First Amendment at all, it seemed to "turn[] more upon the limitations of judicial legislation (by the process of construing) than upon the limitations on legislation by Congress." 164 That is, even if Holmes believed that constitutional law and policy should guide judicial interpretation of the Espionage Act, few imagined that he had erected the First Amendment as a barrier to congressional oversight in the domain of subversive speech.

Assessments of Abrams in the law reviews were notable for their uncertainty. Writing in the Yale Law Journal, Karl Llewellyn concluded that the majority had avoided passing on the constitutionality of the Sedition Act. Given that Justice Clarke "neither agree[d] nor disagree[d] with the view of the First Amendment so cogently put forward in the dissent," Llewellyn thought it possible (if not necessarily likely) that the case would someday "be explained as a mere disagreement on the interpretation of the particular facts involved." 165 In the Michigan Law Review, Thomas Reed Powell considered the dissent to be "difficult to deal with from the standpoint of constitutional law, as it does not make

162 Henry W. Taft, Freedom of Speech and Espionage Act, 55 AM. L. REV. 695, 707 (1921); see also Editorials: Constitutional Law: Freedom of Speech, 5 VA. L. REG. 712, 715-16 (1920) ("We regret to see that Judge Holmes dissented, though not surprised to find that Judge Brandeis did. ... . But Judge Holmes' language in his dissenting opinion is so beautifully characteristic and eminently Bostonian that we are willing to allow him the greatest latitude.").

163 Thomas F. Carroll, Evolution of the Theory of Freedom of Speech and of the Press, 11 Geo. L. J. 27, 41 (1922-1923). Writing three years after the decisions, Carroll concluded that "if Justice Holmes' opinion were accepted, legislative discretion would be further curtailed in this respect by the Court than has been the case in previous instances." Id.

164 L.G.C., Comment on Recent Cases, 14 ILL. L. R. 598, 605 (1919-1920).

165 K.N.L., supra note 101, at 342-43. 
clear how much it is based on the Constitution."166 And John Wigmore, in a notoriously scathing critique of Holmes's opinion, deemed its reasoning "so unclear that its exact point is difficult to gather."167

These ambivalent assessments of Justice Holmes's reasoning raise the question of why the opinion was so widely celebrated. It is my view that the dissent was influential not despite but because of its ambiguous constitutional analysis. Because the majority did not rely on the Sedition Act's categorical prohibitions on abusing the form of Government of the United States, neither the majority nor the dissent were forced to deal squarely with the constitutionality of those clauses. ${ }^{168}$ To Zechariah Chafee, the situation presented was precisely the one that Judge Hand had confronted in Masses Publishing Co. v. Patten. "It is not a question of judicial refusal to enforce legislation," Chafee reasoned, "but of giving it a construction which will not limit discussion beyond the express terms of the Act." 169 This posture meant that progressives could endorse the dissent in Abrams without confronting whether a reversal was constitutionally compelled, or even more controversially, whether it was appropriate for the Court to invalidate democratically enacted legislation. As a result, enthusiastic support for Justice Holmes's appeal to toleration masked deep-seated disagreement among supporters about constitutionalism and the courts.

The Abrams dissent was an opinion written in and for its moment. It coincided with an erosion of progressive confidence in administrative expertise and the judgment of legislative majorities.170 Many of Holmes's longtime admirers felt that the Supreme Court's unanimous decisions in the spring 1919 Espionage Act cases had failed to account for the pathologies of majoritarian democracy and the dangers of

166 Thomas R. Powell, Constitutional Law in 1919-1920, 19 Mich. L. Rev. 283, 291 (1921).

167 John H. Wigmore, Abrams v. U.S.: Freedom of Speech and Freedom of Thuggery in War-Time and Peace-Time, 14 ILL. L. R. 539, 545 (1920).

168 Zechariah Chafee grasped this point and wrote that "the court did not have to declare the clauses involved in the third and fourth counts void." Chafee, supra note 5, at 770. In fact, he presumed that "they are constitutional when construed in accordance with the First Amendment." Id.

169 Id.

170 On contemporary attitudes toward administrative power in the aftermath of World War I, see Daniel R. ERnst, Tocqueville's Nightmare: The Administrative State EMERGES In AMERICA, 1900-1940 (2014); Daniel R. Ernst, Ernst Freund, Felix Frankfurter, and the American Rechtstaat: A Transatlantic Shipwreck, 1894-1932, 23 STUD. AM. PoL. DEV. 171 (2009). I explore the relationship between the erosion of progressive confidence in the administrative state and the emergence of free speech constitutionalism in Weinrib, supra note 27. 
unbridled administrative discretion. It was not that they doubted the legitimacy of state power, as their conservative counterparts did. On the contrary, they believed that the increasing complexities of modern society required careful coordination by a robust administrative state. But, like Chafee, they came to see free speech as a necessary prerequisite for its prudent exercise. The Abrams dissent gave voice to their renewed enthusiasm for open discussion. At the same time, it was suitably vague about the role of the Constitution in constraining state power and, in turn, about the role of the courts in enforcing constitutional limitations.

It was surely relevant both to Holmes's analysis and to the popular reception of the case that the majority sustained the defendants' conviction for advocacy of a general strike at a time when progressives were roundly condemning the deployment of government power to suppress the steel and coal strikes. That issue took on increasing urgency in progressive circles during the fall of 1919. In reporting on the coal and steel strikes, most progressive outlets were more sympathetic to the unions than toward the government officials who intervened on behalf of employers. ${ }^{171}$ Many considered the inequality of bargaining power between employees and employers to be incompatible with democracy and inconsistent with good economic policy. They were also deeply skeptical of the claims that Bolsheviks were behind the strikes. ${ }^{172}$

The link to Abrams was apparent. The dominant reading of the Court's decision, as one law bulletin put it, was that "urg[ing] curtailment of production ... was the only one of the four counts upon which Justice Clarke for the majority seriously attempted to justify the verdict of the jury."173 Abrams was the Court's first encounter with the curtailment clause of the Sedition Act. As a general matter, Clarke was relatively friendly toward organized labor and had evinced support for the right to picket and strike.174 In Abrams, however, he recognized the power of government to prohibit a call to strike-at least when that call was "circulated in the greatest port of our land, ... in which great quantities of war supplies of every kind were at the time being manufactured for transportation overseas."175

The government had explicitly argued in its brief that the purpose of the proposed general strike was "not to improve the conditions of the

\footnotetext{
171 MuRRAY, supra note 111 , at 140.

172 Id.

173 Tully Nettleton, The Philosophy of Justice Holmes on Freedom of Speech, 3 Sw. PoL. SCI. Q. 287, 291 (1923).

174 PolEnBERG, supra note 2, at 206.

175 Abrams v. United States, 250 U.S. 616, 622 (1919).
} 
employees either as to wages or hours of labor."176 Still, the notion that urging workers to strike, absent what Holmes called a "strict and accurate" intent thereby to impede the war effort, was understandably distressing to the labor movement and its allies.177 It was also inconsistent with Holmes's approach to labor cases, ${ }^{178}$ which had vaulted him to the status of progressive icon well before his dissent in Lochner v. New York. ${ }^{179}$ In contrast to most late nineteenth and early twentieth-century judges, Holmes regarded organized labor as an acceptable counterweight to capital, and he had famously declined to impute malicious intent to striking workers. ${ }^{180}$ "The fact, that the immediate object of the act by which the benefit to themselves is to be gained is to injure their antagonist, does not necessarily make it unlawful," he had reasoned in his 1896 dissent in Vegelahn v. Guntner. ${ }^{181}$ Not coincidentally, he had also rejected the majority's assumption that striking workers necessarily issued "threats of force." 182

Much of the early commentary on Abrams made the strike issue central. Writing in the April 1920 Harvard Law Review, Chafee observed that "[s]trikes are not ordinarily illegal, and it would be startling if Congress intended to prohibit all incitement to them in war." 183 Instead, the "statute confined itself to strikes and similar measures that were specifically planned to interfere with the war." 184 Holmes's friend and correspondent Sir Frederick Pollock similarly stressed this problem. If intent were not defined narrowly, "every strike of workmen employed in producing anything of warlike use would be an act of resistance to the

176 Brief on Behalf of the United States at 35-36, Abrams v. United States, 250 U.S. 616 (1919) (No. 316). The purpose, according to the government, was "generally to prevent, at a most critical period of the war, the manufacture and shipment of munitions." Id.

177 Abrams, 250 U.S. at 627 (Holmes, J., dissenting).

178 Holmes later questioned in correspondence whether he was correct to conclude that evidence on the fourth count was insufficient. PolenBERG, supra note 2, at 241.

179 Lochner v. New York, 198 U.S. 45 (1905); HoRWITZ, supra note 104, at 132.

180 Vegelahn v. Guntner, 44 N.E. 1077, 1081 (1896) ("Combination on the one side is patent and powerful. Combination on the other is the necessary and desirable counterpart, if the battle is to be carried on in a fair and equal way.").

181 Id. at 1082.

182 Id. at 1080; see also Nettleton, supra note 173, at 300-01. In Vegelahn, as presumably in Abrams, Holmes drew on the theory he had outlined in 1894 in Oliver Wendell Holmes Jr., Privilege, Malice, and Intent, 8 HARv. L. Rev. 1 (1894). See HorwiTZ, supra note 104, at 131-36.

183 Chafee, supra note 5, at 767.

184 Id. "If these defendants were guilty under the fourth count," he explained, "so was every other person who advocated curtailment in the production of war essentials, no matter what his purpose." Id. at 768. Chafee also argued that the call to a general strike was formulaic rather than genuine. "We ought to hesitate a long while before we decide that Congress made such shop-worn exuberance criminal," he argued. Id. at 758. 
United States," even if it were motivated by a dispute over wages and hours. 185

Of course, academic discussion of the Abrams dissent was never limited to the curtailing production count. From the outset, the opinion was understood as an endorsement of open discussion. As the failed coal and steel strikes receded from view - and as Holmes and Brandeis began dissenting in a broader range of speech cases-Holmes's celebration of the free trade in ideas became a progressive rallying cry.

In thinking better of his own earlier concessions to repression, Holmes was by no means aberrational. True, a few lonely voices worried with progressive John Wigmore that the Court's "parlor Bolsheviks" were abetting the circulation of violent propaganda in the name of "good-natured tolerance" - and indeed, that the risk was higher in peacetime, as the "forces of impatient fanaticism [were] let loose upon our constitutional government," than it had been during the war. 186 Conservative lawyers, on the whole, shared Wigmore's sense that the Supreme Court majority had helped to hold off a Bolshevik coup. Many Americans, however, were losing their taste for suppression, and the Palmer Raids and the deportations that followed unleashed a flood of critical commentary. In January, the New York Assembly's refusal to seat lawfully elected socialists prompted widespread outrage, along with a public repudiation by Charles Evans Hughes on behalf of the New York Bar Association. ${ }^{187}$ The repressive wave in New York lost its momentum, ${ }^{188}$ and despite his best efforts, Attorney General Palmer failed to persuade Congress to enact a federal peacetime sedition law. 189 To be sure, anti-Red sentiment persisted, and state legislatures continued to pass criminal syndicalism and sedition statutes well into the following year. 190 Still, it was clear that the tide had turned. As Herbert Goodrich observed in an article on the constitutional protection of free speech, "We no longer jump with apprehension at hearing the

185 Frederick Pollock, Abrams v. United States, 36 L. Q. REv. 334, 336 (1920).

186 Wigmore, supra note 167 , at 560.

187 Albany's Ousted Socialists, Literary Digest, Jan. 24, 1920, at 19; Brief OF SPeCial CommitTEE Appointed By the AsSociation of the BAR OF THE City of NEW YoRk (1920). Chafee wrote that "with Governor Hughes's letter on the 9th, the ebb set in." CHAFEE, supra note 132 , at 338.

188 See Thomas E. Vadney, The Politics of Repression: A Case Study of the Red Scare in New York, 49 N.Y. Hist. 56, 71-72 (1968); Julian F. JafFe, Crusade Against Radicalism: New YORK DURING THE RED SCARE 147-50, 239 (1972).

189 JAFFE, supra note 188, at 177; National Civil Liberties Bureau, This Little Story is Entitled 'God Bless the Lusk Committee', Jan. 28, 1920, in Records of the American Civil Liberties Union, Swarthmore College Peace Collection, Swarthmore, Penn., Box 1.

190 MurPhy, supra note 8, at 42; see also PRESTON, supra note 32. 
word 'Bolshevist."'191 In fact, by March 1920, the liberal Republican Joseph I. France could declare on the Senate floor that in comparison with the confiscation of property, it is "a worse form of bolshevism which confiscates real and personal rights." 192

This period witnessed a revival among progressives (who increasingly were referring to themselves as liberals) of the language of constitutionalism, layered upon a critique of administrative abuses in the policing of suspected subversives. In the summer of 1920, Zechariah Chafee was among the twelve lawyers and legal academics who issued the influential Report upon the Illegal Practices of the United States Department of Justice. ${ }^{193}$ The group, which also included Ernst Freund, Felix Frankfurter, and Roscoe Pound, condemned the Wilson administration for its lawless methods and its "continued violation of [the] Constitution," including the "[w] holesale arrests both of aliens and citizens ... without warrant or any process of law."194 Although the report emphasized the Fourth, Fifth, and Eighth Amendments rather than the First, Chafee considered the Department of Justice (together with the Post Office) to be equally accountable for abridging First Amendment freedoms. Harry Weinberger and other civil liberties lawyers welcomed the outcry that public accusations by such prominent figures helped to generate. "The more frequent the disregard of the Constitution[] ... displayed by civil and military officials and by the courts themselves," pronounced the League for Amnesty of Political Prisoners (of which Weinberger was a legal advisory board member), "the more dangerous the sentiment of resentment and lawlessness will become."195

The new enthusiasm for constitutional rights did not, however, translate into a judicial mandate for enforcing them. The Abrams dissent, along with a handful of speech-protective Espionage Act cases in the lower courts, ${ }^{196}$ suggested the potential for courts to constrain lawless officials. Chafee himself was instrumental in litigating an important victory in a 1920 deportation case, though the decision was subsequently overturned on appeal. ${ }^{197}$ Nonetheless, most progressives

191 Goodrich, supra note 10 , at 487.

19259 Cong. REc. 4685 (1920) (statement of Joseph I. France).

193 Nat'l. Popular Gov't League, To the American People: Report upon the Illegal Practices of the United States Department of Justice (1920).

194 Id. at 3.

195 League for Amnesty of Political Prisoners, Is Opinion a Crime?, in ACLU Papers, supra note 31, vol. 116.

196 See MurPhy, supra note 33, at 179-247.

197 Colyer v. Skeffington, 265 F. 17 (D. Mass. 1920). On Colyer v. Skeffington, see Donald L. Smith, Zechariah Chafee JR., Defender of LiberTy AND LaW 47-50 (1986); Peter 
continued to regard the courts with distrust, if not downright disdain. After all, the Red Scare had only exacerbated their impression that the courts elevated property rights over personal rights. Judges (as well as juries) had proven enthusiastic censors in the wartime case. Not only had they permitted Espionage Act prosecutions to go forward but they had actively expanded the sweep of the statutes through the doctrines of "bad tendency" and constructive intent. As Ernst Freund put it, the locus of decision-making had simply shifted from an "arbitrary executive" to "arbitrary judicial power."198

How, then, did progressives imagine that freedom of speech might be vindicated? Anticipating later calls for constitutionalism outside the courts, progressives looked to legislators and administrators to exercise moderation. Even Zechariah Chafee accepted, after Abrams, that trial judges were inclined to construe sedition statutes in a speech-restrictive fashion, and the Supreme Court was unlikely to stand in the way. "The lesson of United States v. Abrams," he concluded "is that Congress alone can effectively safeguard minority opinion in times of excitement."199 It was up to Congress to "change or abolish the Sedition Act of 1918, so that in future wars such a trial and such sentences for the intemperate criticism of questionable official action shall never again occur in these United States." 200

In short, few progressives imagined that endorsing the Abrams dissent required accepting a role for court-centered constitutionalismand the handful who deemed the issues inseparable opted to reject the Abrams dissent instead. For example, in reflecting on the Abrams decision, constitutional scholar Edward Corwin noted that many of the same scholars who were "endeavoring to-day to elaborate constitutional restrictions upon Congress's power over the press" had previously opposed the judicial enforcement of "constitutional limitations" on congressional power. In Corwin's view, the reversal was ill-advised; "[I]t [was] much more to the point to insist upon the responsibility of legislators than their lack of power."201 In a similar

H. Irons, "Fighting Fair": Zechariah Chafee, Jr., The Department of Justice, and the "Trial at the Harvard Club," 94 HARv. L. REv. 1205, 1219-28 (1981).

198 Ernst Freund, The Debs Case and Freedom of Speech, New Republic, May 3, 1919, at 14 .

199 Chafee, supra note 5, at 773; see also CHAFEE, supra note 132, at 3-6 (describing the First Amendment as "an exhortation and a guide for the action of Congress").

200 Chafee, supra note 5, at 774.

201 Edward S. Corwin, Freedom of Speech and Press under the First Amendment: A Resume, 30 YAle L.J. 48, 55 (1920); see also Edward S. Corwin, Constitutional Law in 19191920, 14 AM. PoL. SCI. REv. 635, 658 (1920) ("[T]he cause of freedom of speech and press is largely in the custody of legislative majorities and of juries."). 
vein, Herbert Goodrich inverted Holmes's appeal in Abrams to the "free trade in ideas." He pointed approvingly to an emerging consensus that Lochner v. New York was wrongly decided and speculated that a similar logic would "uphold a law limiting the exercise of [one's] tongue when the majority so wills it."202 In Goodrich's estimation, the progressive critique of freedom of contract had prevailed in the marketplace of ideas. "If unrestricted speech cannot win in the same field," he said, "we shall probably have to get along without it."203

\section{ABRAMS, AMNESTY, AND LEGAL LEGITIMACY}

Simply put, in the aftermath of the Abrams dissent, neither lawyers nor legal scholars pressed Justice Holmes's opinion into the service of legal liberalism.204 Progressives on the whole remained skeptical of court-centered constitutionalism and preferred to constrain majoritarian overreach and administrative arbitrariness through other means instead. For their part, the conservatives who valorized the judiciary as a "citadel of justice" continued to distinguish between liberty and license, and they assigned subversive advocacy to the (unprotected) license side of the line. ${ }^{205}$

That the Abrams dissent was not used to promote the judicial enforcement of the First Amendment does not, however, mean that it was not used at all. In winter 1920, West Publishing Company ran an article entitled "Soviets and Sedition," in which it reported that the Abrams case was "interesting and important, not only because of the dissenting opinion of Mr. Justice Holmes, but because of the use which the radical and revolutionary forces are already making of it in justifying their propagandism."206 That "propagandism" took a particular form. The Abrams dissent was mobilized not to advance the judicial enforcement of personal and procedural rights but to prove that justice was unavailable to radical defendants in the courts.

\footnotetext{
202 Goodrich, supra note 10 , at 500.

203 Id.

204 On the centrality of judicial review to American liberalism, see, e.g., LouIS HARTz, The Liberal Tradition in America 9 (1955); Laura Kalman, The Strange Career of Legal LIBERALISM 20-27 (1996).

205 Calvin Coolidge, A Platform of Business Principles, NATION's BusinEss, Dec. 1924, at 37.

206 Soviets and Sedition, 3 West PuB. Co. Docket 2207, 2207 (1920); see also C.W. German, An Unfortunate Dissent, 20 U. Mo. Bull. L. SER. 65, 80 (1920) (“[T]he 'Rebels' and 'Revolutionists' will be quick to seize upon this dissenting opinion and every phrase therein, and send it out as propaganda to their fellows, thus destroying in large measure the beneficent result of the conviction of these defendants and the otherwise salutary effect of the affirmance of that conviction by a majority of this great court.").
} 
Advocates immediately identified the persuasive potential of the opinion in pursuit of their preferred remedy for the wartime suppression, which (in keeping with Progressive Era beliefs about institutional role) relied on the political branches rather than the courts: the campaign for a blanket amnesty of the Espionage Act defendants. Before and even during World War I, civil liberties groups had scored modest successes through negotiations with progressive officials. ${ }^{207}$ The amnesty effort, spearheaded by a range of pacifist and radical organizations, initially had looked similarly promising. The NCLB's Roger Baldwin voiced a common sentiment when he speculated that "all these long sentences are merely paper" - that there would be a "general amnesty for political prisoners after the war." 208 Even before the armistice, respected public figures were urging "enlightened humanity" in the treatment of those imprisoned for criticizing the draft or American participation in the war. ${ }^{209}$ When the war ended, advocates were optimistic. ${ }^{210}$ Progressive senators proposed a general amnesty for those convicted during the war by court-martial, pointing to arbitrariness in sentencing. ${ }^{211}$

But these early efforts faltered, and a general amnesty for Espionage and Sedition Act defendants never materialized. Although President Wilson considered granting a partial amnesty, his advisors dissuaded him from doing so.212 Attorney General Thomas Gregory and his successor, A. Mitchell Palmer, each recommended about fifty commutations, and both were open to leniency in particular cases (a concession that only confirmed to advocates that "justice in America is a matter of favor and influence").213 But in the summer of 1919, when

207 See generally Jeremy Kessler, The Administrative Origins of Modern Civil Liberties Law, 114 Colum. L. Rev. 1083 (2014); Laura M. Weinrib, Freedom of Conscience in War Time: World War I and the Limits of Civil Liberties, 65 Emory L.J. 1051 (2016).

208 Letter from Roger Baldwin to Stella Comyn Ballantine (July 29, 1918), in ACLU Papers, supra note 31, vol. 26. Baldwin himself was sentenced to one year in prison for refusal to submit to the draft. COTTRELL, supra note 37, at 83-88.

209 Letter from Upton Sinclair to President Wilson (Oct. 1918), in ACLU Papers, supra note 31 , vol. 50 .

210 Capital Looks to Wilson for Repeal of Gag and Amnesty, N.Y. CALL, Feb. 26, 1919, in ACLU Papers, supra note 31, vol. 53; see also Liberties Bureau Takes Issue with Gregory (newspaper clipping), in ACLU Papers, supra note 31, vol. 43 (citing President Thomas Jefferson's general amnesty for those convicted under the Sedition [Act] of 1798, which was "a statute far less drastic than the Espionage [A]ct.").

211 Proposes Amnesty For Army Offenders, N.Y. CALL, Jan. 28, 1919, in ACLU Papers, supra note 31, vol. 41.

212 JoHnson, supra note 37, at 109-18.

213 Liberties Bureau Takes Issue with Gregory (newspaper clipping), in ACLU Papers, supra note 31, vol. 43. Mollie Steimer repeatedly rejected efforts to obtain a commutation on this basis. See, e.g., Mollie Steimer Spurns Mercy, N.Y. CALL, Feb. 24, 1921 
President Wilson expressed willingness to pardon "all American citizens in prison or under arrest on account of anything they have said in speech or in print concerning their personal opinions,"214 Palmer insisted that no such cases existed.215

Determined to overcome these setbacks, proponents of a general amnesty fought even harder to sway public opinion and to persuade sympathetic officials. In that effort, the Abrams dissent seemed a promising weapon. Less than two weeks after the decision was handed down, Weinberger told the ACLU's Albert DeSilver that "in view of Judge Holmes' opinion, ... every American should understand that Amnesty should be declared." 216 In fact, he thought "effective work for amnesty can be swung around this case, as well, if not even better than the Debs case, because of the outrageous sentence."217 DeSilver enthusiastically agreed. "I think that the dissenting opinion in the Abrams case is a wonder," he responded. "We are going to put it to some use all right." 218

Two features of Abrams made it especially appealing. The first was the "ferocious sentences" (as the Nation described them ${ }^{219}$ ) that Judge Clayton meted out. As a general rule, the amnesty campaign emphasized the "inequalities attending the administration of justice."220 Disparities in sentences implied that judges were arbitrary or even vindictive, and they buttressed the case for executive intervention. In November 1919, Weinberger wrote to the socialist leader and Presbyterian minister Norman Thomas, enclosing a copy of a favorable editorial in the mainstream press. "Americans who run and only read headlines of plots, bombs, reds, etc., can even understand that these boys ought not to go to jail for 20 years," 221 he told Thomas. Thomas evidently agreed. The World Tomorrow, the Christian socialist newspaper that Thomas edited, soon cited the case as the "clear[est] proof" yet of the

("If a general amnesty will be given ... it will be well, of course. If not, I am determined to serve my term with a smile, and am absolutely opposed to any individual appeals on my behalf.").

214 Two Telegrams from Woodrow Wilson to Joseph Patrick Tumulty, Jun. 28, 1919, in 61 The PAPERS OF Woodrow WiLson 351-352 (Arthur S. Link et. al, eds., 1989).

215 Political Prisoners in U.S. Total 1,500, Estimates Bureau, N.Y. TRIB., Apr. 13, 1919.

216 Letter from Harry Weinberger to Albert DeSilver (Nov. 22, 1919), in ACLU papers, supra note 31, vol. 91.

217 Id.

218 Letter from Albert DeSilver to Harry Weinberger (Dec. 1, 1919), in ACLU papers, supra note 31, vol. 91.

219 Our Ferocious Sentences, NATion, Nov. 2, 1918, at 504.

220 Editorial, Release Political Prisoners, DiAL, Jan. 11, 1919, at 6.

221 Letter from Harry Weinberger to Norman Thomas (Nov. 26, 1919), in Harry Weinberger papers, Box 2, Folder 11. 
"breakdown of our so-called democracy" and asked whether "any sentence under the Czar's regime was ever more cruel." 222

Second, and relatedly, Weinberger and other advocates of amnesty underscored the abuses and irregularities that suffused the investigation and trial.223 They wagered correctly that respectable Americans would rally to the cause of procedural fairness even if they were ambivalent about the underlying offenses. That was a lesson that civil liberties lawyers had internalized during World War I and used to good effect during the Red Scare.224 After all, "a fair trial in a court of justice" was a well-established constitutional right.225 Of course, procedural fairness was insufficient to safeguard radical agitation or unpopular ideas. ${ }^{226}$ Still, appeals to rule of law resonated broadly, and they could buttress support for executive intervention or administrative tolerance. During the two years between the Supreme Court's decision in Abrams and the defendants' eventual deportation, amnesty proponents repeatedly justified their efforts by reference to the case. In the summer of 1920 , Wilson challenged amnesty groups to identify a single citizen who was in prison due to unjustifiable persecution. ${ }^{227}$ The ACLU responded in a public letter stating that the Abrams defendants were serving fifteen- and twenty-year sentences for the distribution of handbills "which, in the opinion of Mr. Justice Brandeis and Mr. Justice Holmes, they had as much right to distribute as the Constitution of the United States." 228

Abrams had appeared in amnesty literature even before the Supreme Court issued its decision. In a pamphlet entitled "Why Should There Be an Amnesty," the NCLB invoked the case as a prime example of judicial misconduct. "The record of the trial abounds with instances of the atmosphere of prejudice and rancor that filled the court-room," it

222 Views and Reviews: America 1620-1920, World Tomorrow, Jan. 1920, at 2.

223 See, for example, Harry Weinberger to Zechariah Chafee, Feb. 4, 1920 in Zechariah Chafee Papers, Box 29, Folder 11 (emphasizing "the intolerance of the judge," the skewed composition of the jury, and the "third degree"); and Mollie Steimer and 3 Youths to Be Released, N.Y. CALL, Oct. 16, 1921 (attributing the "particular public attention" the case received to the severity of the sentences and the "strikingly unjudicial attitude of the court in imposing them").

224 WEINRIB, supra note 11 , at ch. 3.

225 Davidson v. New Orleans, 96 U.S. 97, 105 (1878).

226 On the limits of a civil liberties strategy built around procedural fairness, see Laura Weinrib, Untangling the Radical Roots of America's Civil Liberties Settlement: Causation, Compromise, and the Taming of Free Speech, 18 JERUSALEM R. L. STUD. 88 (2018).

227 FEDERATED PREss, June 20, 1920 (newspaper clipping), in ACLU papers, supra note 31, vol. 113.

228 Id. 
reported.229 But it was one thing for advocates to describe a trial as biased, and another to rely on a justice of the United States Supreme Court. A minority opinion by Justice Holmes was capable of convincing even "capitalistic newspapers" that an "intolerable injustice" had occurred. ${ }^{230}$ However loudly radicals and pacifists might complain of injustice, their cries echoed faintly in comparison with a reference in the New York American to "the painful spectacle of four persons imprisoned practically for life for printing a leaflet which two of the Justices of the Supreme Court flatly assert they had a perfect legal right to print."231 Exploring the plight of "political prisoners" for the Survey in August 1920, the social worker Loula Lasker cited Abrams as the "case which has probably been called most forcibly to the attention of the public."232

Weinberger's effort to characterize the trial as incompatible with the norms of legal legitimacy found its most powerful champion in Zechariah Chafee, who believed that the Supreme Court's failure to reverse the conviction had shifted the responsibilities to the "pardoning authorities ... to remedy the injustice."233 Relying on his correspondence with Weinberger and on the publicity materials that Weinberger prepared and supplied, Chafee argued in the Harvard Law Review that "the whole proceeding, from start to finish, has been a disgrace to our law." 234 He described the "systematic arrest of civilians by soldiers on the streets of New York City" as an unprecedented departure from legal norms. ${ }^{235}$ Although the witnesses who arrested and interrogated the defendants denied abuse, Chafee considered the allegations of brutality, which were "disquietingly specific and sincere," to be troubling. ${ }^{236}$ At trial, Judge Clayton had breached the norms of judicial neutrality by cross-examining the witnesses and allowing the jury to convict the defendants "for their Russian sympathies and their anarchistic views." 237 He had routinely interrupted and ridiculed them ("[l]egal historians," Chafee forewarned, "have always taken interest in

\footnotetext{
229 Why Should There Be an Amnesty, in ACLU Papers, supra note 31, vol. 69.

230 League for the Amnesty of Political Prisoners, Is OPinion A CRime?, in ACLU Papers, supra note 31, vol. 116.

231 Id. (quoting Editorial, New York AMERICAN, Nov. 13, 1919).

232 Loula D. Lasker, America and Her "Political Prisoners,"SuRveY, Aug. 2, 1920, at 578.

233 Chafee, supra note 5, at 774.

234 Id.

235 Id. at 773. On Weinberger's influence on Chafee, see PolEnBERG, supra note 2, at 272-84; Irons, supra note 197, at 1230-31.

236 CHAFEE, supra note 5, at 761, 773.

237 Id.
} 
the criminal judge who jests with the lives of men"). ${ }^{238}$ And the sentences he handed out were outrageously long. Indeed, they could not have been longer had the defendants "tie[d] up every munition plant in the country." 239 Chafee stressed that he had no affinity for the defendants' underlying political and economic views. "My sympathies and all my associations are with the men who save, who manage and produce," he later told the Harvard Club. But he wanted his "side to fight fair," and he regarded the Abrams prosecution "as a distinctly unfair piece of fighting." 240

To be sure, Chafee's account of the trial was not universally accepted. ${ }^{241}$ But the article went a long way toward shaping the public perception of the case. Frederick Pollock drew heavily on Chafee's account in describing Abrams as a "singular disregard of judicial fairness and of the principles of justice," and he echoed Chafee (and, in turn, Weinberger) in describing Judge Clayton's sentences as draconian.242 Other lawyers and scholars followed suit. When a newly organized bar association committee sought an example of wartime abuses, the ACLU pointed to Abrams. "I guarantee that that record will shock any openminded lawyer," Albert DeSilver offered, citing Chafee's "admirable analysis of it in the current number of the Law Review."243 Chafee also drew the case to the attention of his colleagues at Harvard Law School, who responded with outrage. Felix Frankfurter had "no hesitation" in pronouncing it the "most disgraceful record of a criminal case" in the federal courts that he had ever read.244 Frankfurter and Roscoe Pound both joined Chafee in signing a petition to President Wilson requesting amnesty for the defendants. ${ }^{245}$

In the end, advocates' efforts to leverage the Abrams case into a general amnesty were unsuccessful. On the campaign trail in October 1920, Warren G. Harding conveyed that he saw "no essential differences between ordinary crimes and ordinary criminals on the one hand, and

\footnotetext{
238 Id. at 762.

239 Id. at 763.

240 Irons, supra note 197, at 1233.

241 It provoked an attack by Harvard alumni and eventually an inquiry into Chafee's academic integrity. See generally Irons, supra note 197, at 1206.

242 Pollock, supra note 185, at 335 (stating that "a similar offence in England ... would be imprisonment for six months, or twelve at the outside"). Pollock's account itself influenced American opinions. See, e.g., An English Criticism of a Decision of the Supreme Court of the United States, 92 CENT. L.J. 369 (1921).

243 Letter from Albert DeSilver to Oswald Garrison Villard (May 8, 1920), in ACLU Papers, supra note 31, vol. 135.

244 Letter from Felix Frankfurter to Julian Mack (May 12, 1921), in Zechariah Chafee Papers, Box 29, Folder 21.

245 Irons, supra note 197, at 1212.
} 
political crimes and political prisoners on the other hand."246 Harding's attorney general was similarly unencouraging in a 1921 address to the American Bar Association. Pronouncing it "the duty of the minority as well as the majority to obey the law," and the responsibility of the Department of Justice to enforce it, Harry Daugherty enjoined "those who do not believe in our government and the enforcement of our laws [to] go to a country which gives them their peculiar liberty." 247 Throughout the 1920s, lawyers and advocates exerted quiet pressure on Washington and negotiated commutations for a few prisoners at a time. Only in 1933 did President Franklin D. Roosevelt finally issue a blanket amnesty of the wartime prisoners.

As for the Abrams defendants, after much wrangling, Weinberger secured commutations of their sentences in exchange for deportation to the Soviet Union at their own expense. In that effort, too, the Abrams dissent proved instrumental. As the Miami Valley Socialist explained, "The fact that a dissenting opinion was rendered by Justice Holmes [was] used as the basis for the appeal for executive clemency." ${ }^{248}$ Harding agreed to release the defendants in November 1921, one month before the release of Eugene V. Debs. According to the New York Call, it was the final chapter of "one of the most celebrated of all the cases brought under the Espionage Act."249 It was in Abrams, the Call reminded readers, that Justices Holmes and Brandeis had first denounced that "interpretation of justice which deprived the defendants of their constitutional rights." 250

\section{CONCLUSION}

Today, Justice Holmes's dissent in Abrams v. United States is remembered as a blueprint for the modern First Amendment, a harbinger of the judicial enforcement of civil liberties. In its day, that characterization of the opinion would have been baffling. In the 1920s, organized opposition to the prosecution of political dissenters drew heavily on Justice Holmes's dissent in the Abrams case. But the goal of

246 Harding Is Against Amnesty, PhIL. Evening LEDGER, Oct. 8, 1920, reprinted in LucY Robins, A DOCUMENTAL STORY OF THE STRUGGLE For AMNESTy 209-10 (1922) (adding that if there was any difference, it was "the political conspirator who is the greater menace to the United States").

247 Harry M. Daugherty, Respect for Law, 44 Annu. ReP. A.B.A. 190, 203-04 (1921).

248 Dissenting Opinion Used in Fight for New Steimer Trial, Miami Valley Socialist, May 14, 1920, in ACLU Papers, supra note 31, vol. 158.

249 Mollie Steimer and 3 Youths to Be Released, N.Y.CALL, Oct. 16, 1921, in ACLU Papers, supra note 31, vol. 177.

250 Orders Issued for Deporting Mollie Steimer, N.Y.CALL, Oct. 21, 1921, in ACLU Papers, supra note 31, vol. 177. 
that publicity was to discredit the judiciary as an institution, not to bolster it. In promoting Justice Holmes's articulation of the procedural infirmities of the Abrams trial, advocates could not have anticipated that the dissent would someday be remembered as an emblem of courtcentered constitutionalism.

The point is not that contemporaries failed to appreciate Holmes's articulation of the value of free speech. On the contrary, Holmes's colorful turns of phrase were accorded pride of place in pamphlets and editorials, and the fledgling ACLU eagerly incorporated the opinion's most memorable paragraph into its new statement of principles. ${ }^{251}$ Yet Holmes's disagreement with the majority was not invoked in support of a positive program to strengthen judicial review. It was offered instead as evidence of the "extent of the Courts' departure from the principle of civil liberty." 252 Put simply, it was clear after Abrams that "the Supreme Court [had] gone over to the side of reaction." 253 And the only tenable solution was to weaken judicial power.

A pair of articles in the New Republic captures this approach well. Throughout the 1920s, the New Republic adhered to its earlier, progressive view that the legislature was the institution best suited to policing the First Amendment. The solution to unjust laws, its editors insisted, was to repeal them-not to seek their invalidation in the courts. It was therefore unsurprising when a December article on Abrams reached two preliminary conclusions about its effects. First, it presumed that the court had "succeeded in making out of four unbalanced and incoherent Russians four martyrs in the cause of true Americanism"; after all, there was no surer way to make martyrs of agitators than to imprison them for the expression of ideas. ${ }^{254}$ The second implication was no less unexpected. With Abrams, the Court had "shifted to Congress the task of preserving the spirit of the First Amendment as a living force in American law." 255

The following April, in an article entitled "The Supreme Court vs. the Supreme Court," the New Republic once again examined the Abrams case. ${ }^{256}$ This time, it juxtaposed the Court's wartime speech decisions, which it characterized as cases involving "human rights," with its

\footnotetext{
251 Letter from Walter Nelles to Roger Baldwin (Dec. 11, 1919), in ACLU Papers, supra note 31 , at vol. 120 .

252 ACLU, The Supreme Court vs. Civil Liberty 1 (1921), in ACLU Papers, supra note 31, at vol. 69 .

253 Id.

254 Gerard C. Henderson, What is Left of Free Speech, New Republic, Dec. 10, 1919, at 52 .

255 Id.

256 The Supreme Court vs. the Supreme Court, New RePublic, Apr. 21, 1920, at 235.
} 
decisions involving "property rights." 257 According to the editors, reading the two categories of cases together demanded a "consideration of the safeguards to be imposed upon the extraordinary judicial power of the Supreme Court."258 Although they acknowledged that the justices' views did not line up squarely along the lines of class interest, they thought it clear that the Court "manifest[s] a different attitude towards the acquisition and protection of property than towards other aspects of human liberty."259 Complications aside, they continued, "No candid student of Supreme Court decisions can say that some of its members do not, unconsciously at least, illustrate the economic interpretation of history." 260 The editors did not offer a solution. They did, however, question "the wisdom of leaving the ultimate law-making power of the nation to nine men." 261

That critics of the Court impugned the justices simultaneously "for sustaining or for overthrowing acts of Congress" was not lost on conservatives. ${ }^{262}$ Assessing "the new attack upon the independence of the judiciary," the presiding judge of the Kansas Court of Industrial Relations identified three principal categories of cases "productive of the present campaign to discredit the courts and to limit their power." 263 Two of those categories-judicial decisions curbing union activity and invalidating social and economic legislation-involved longstanding grievances. ${ }^{264}$ The third was a new addition to "propaganda against the courts": "the alleged invasion of free speech and free press by such decisions as the Abrams case." 265

For the time being, progressives continued to regard the three faces of judicial malfeasance as intimately related. That was a position articulated forcefully by Wisconsin Senator Robert La Follette, "the recognized champion of the movement to limit the power of the courts." 266 A former law partner of the civil liberties lawyer Gilbert Roe, he was also an outspoken advocate for free speech. ${ }^{267}$ In fact he was among the few senators who had opposed the Espionage Act and had

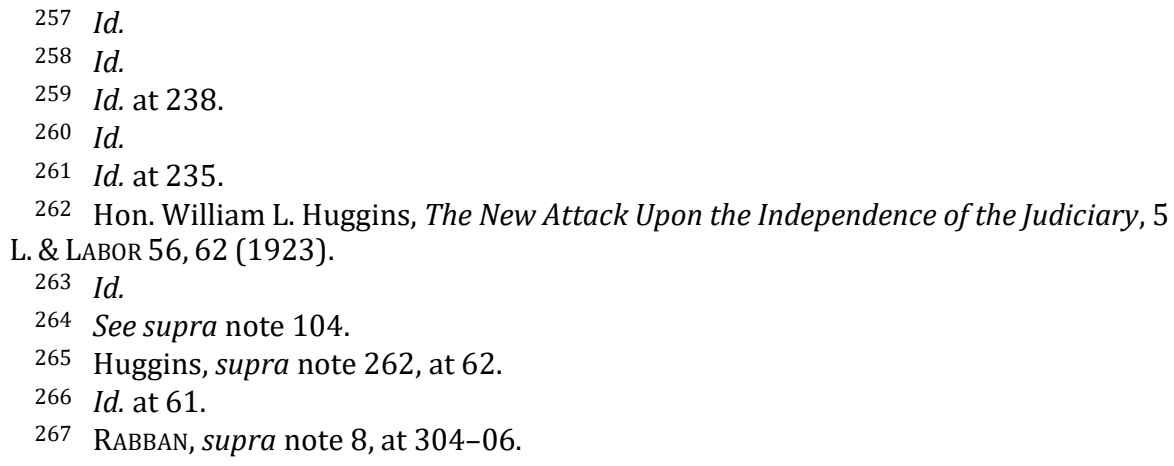


pushed to preserve open channels "for free public discussion of governmental policies" during the war. 268 For over a decade, La Follette had believed that democratic legitimacy required greater popular oversight of the courts, and he had proposed court-curbing mechanisms ranging from the recall of judges to a congressional override of Supreme Court decisions. Speaking to the 1922 annual convention of the American Federation of Labor, he pointed to a long list of state and federal cases invalidating progressive reform legislation and undermining union power. ${ }^{269}$ But alongside the many judicial decisions exercising judicial authority to undermine social and economic progress, La Follette held out Abrams for special reprobation. "To my mind this case, involving the fundamental right of freedom of speech, best illustrates the extreme length to which the court is prepared to go under the influence of its prejudices and passions," he said. ${ }^{270}$ After Abrams, it was time to "face[] the fundamental issue of judicial usurpation squarely ... once and for all."271 Notably, La Follette's view found ample support among the champions of free speech. The organizations that endorsed his proposed constitutional amendment to abolish judicial review of congressional legislation included the ACLU, which emphasized in a 1924 statement that "the courts had been as flagrant violators of civil liberties as the legislative and executive branches of government." 272

The theory of the First Amendment we now associate with Abrams $v$. United States would not take root for at least another decade. The story of its success is a messy and protracted one. In part, the old progressive preference for toleration and accommodation in the political branches seemed increasingly fanciful, and the potential for administrative overreach increasingly grave. In any case, the selfdescribed "partisans of labor" who spearheaded the interwar civil liberties movement and founded the ACLU had never trusted the state as progressives did.273 Their efforts to secure protection for labor's rights to picket and boycott would lead them to advocate a strong First

268 Free Speech in Wartime, 65 ${ }^{\text {th }}$ Cong., 1st Sess. (1917) (statement of Senator Robert La Follette), in Robert C. Byrd et AL., The Senate, 1789-1989 521-24 (Wendy Wolff ed. 1994).

269 Senator Robert M. La Follette, Address at the Forty-First Annual Convention of the American Federation of Labor (June 14, 1921), in 66 Cong. REc. (June 25, 1922).

270 Id. at 13

271 Id.

272 ACLU, Free Speech in 1924: The Work of the AmericAn Civil Liberties Union January TO DECEMBER 192430 (1925).

273 Walter Nelles, Suggestions for Reorganization of the National Civil Liberties BuREAU, ACLU Papers, supra note 31, at vol. 120. 
Amendment, and eventually and ambivalently, to seek its enforcement in the courts.

Along the way, they would forge an unlikely alliance with a cadre of conservative lawyers. Already in 1920, a self-described "Conservative Constitutionalist" writing in praise of the Abrams dissent deemed it necessary to protect the "free trade in ideas," lest propaganda prosper, "false news" go unanswered, and "minorities perish." 274 A few years later, as labor militancy and radical agitation receded into hazy memory, his admittedly aberrational assessment would begin to attain broader purchase. With the specter of revolution safely behind them, conservatives could embrace Justice Holmes's proclamation that the "surreptitious publishing of a silly leaflet by an unknown man" posed little danger to American institutions. ${ }^{275}$ Free speech came at low cost, with large potential gains for property rights and judicial legitimacy.

When the Supreme Court issued its decision in Abrams v. United States, and Justice Holmes penned his historic dissent, all of this was in the future. In 1919, no one envisaged that Holmes would persuade the Court to extend First Amendment protection to subversive expression. For the time being, the justices showed no inclination to "doubt either [their] power or [their] premises." 276 There was little indication that free speech would become a core constitutional commitment, let alone a formidable constraint on government authority.

Notably, the New Republic predicted that Justice Holmes's dissent in Abrams would "bulk as important in future discussion of the judicial interpretation of legislation which limits freedom of speech as the same Justice's dissenting opinion in the case of Lochner vs. New York did in relation to judicial interpretation of laws which invoked the police power."277 To draw out the parallel, they anticipated that the opinion would influence scholarly opinion. They thought it would serve as a rallying cry and a catalyst for public debate. But it would have been foolish to expect Holmes to sway his fellow justices to protect unfettered speech, any more than he had convinced them to abandon liberty of contract. In fact, contemporaries saw the two decisions as sides of the same coin. As an early comment on the case observed, Abrams ensconced the Constitution as "an airtight, four-walled compartment

274 George Palmer Garrett, Free Trade in Ideas, 11 J. Am. Inst. Crim. L. \& Criminology 181, 184-89 (1920).

275 Abrams v. United States, 250 U.S. 616, 628 (1919), (Holmes, J., dissenting).

276 Id. at 630.

277 The Call to Toleration, New Republic, Nov. 26, 1919, at 360. 
designed to preserve at all costs the status quo economically as well as politically." 278

That was hardly a path to deliberative freedom. Indeed, the staunchest interwar advocates of the First Amendment regarded Abrams as the deathblow to constitutional litigation in pursuit of free speech. Despite its stirring dissent, the Abrams case had left "the status of civil liberty hopeless so far as it is the concern of courts of law." 279

278 L.G.C., supra note 164 , at 607.

279 Walter Nelles, Suggestions for Reorganization of the National Civil Liberties BuREAU, ACLU Papers, supra note 31, at vol. 120. 